\title{
Difficulties observed in operating powered roof support during work in lower range of its working height
}

\begin{abstract}
Significant maintenance difficulties have recently been observed in terms of the proper maintenance of mining roofs during the operation of powered roof supports in their low section height range, which is characterized by a wide working range. These difficulties were also encountered in situations where the calculated load capacity index of the roof " $g$ " reached favorable values. These phenomena occurred most often during extraction under gobs and when maintaining a protective roof carbon shelf of the required thickness. This paper presents the calculations and analyses aimed at clarifying and discussing these events.
\end{abstract}

Key words: powered roof support, bearing capacity, forces, evaluation

\section{INTRODUCTION}

Introduced for use in previous years, powered roof supports were equipped with legs of large diameters, enabling the development of significant forces due to the conditions of the designed extraction. The aim is to obtain wide ranges in the working span of the sections, as the mining companies want to apply universal roof supports that can be used in seams with different thicknesses. As a result, the created systems are characterized by larger sizes and load-bearing capacity levels than those used so far; therefore, they have led to problems and issues that have not been observed before. Increasing the size of a powered roof support results in the larger dimensions of an excavation, causes a greater load from the rock mass, and generates greater forces in the construction nodes. Consequently, it is essential to ensure the appropriate strength parameters of the roof support and good design of its kinematics, which in turn should ensure its correct cooperation with the rock mass, guaranteeing the fulfillment of the requirements arising from the geological and mining conditions of future areas of extraction.

This article presents the results of the calculations and analyses of the two types of powered roof support construction heights ranging from 2.4 to $4.6 \mathrm{~m}$ and internal diameters of the first stage legs reaching $320 \mathrm{~mm}$ (hereinafter referred to as OBUD-1 and OBUD-2, which are used in the Mysłowice-Wesoła Coal Mine in the floor layer of Seam 510 in Longwall 124 under the upper layer of the gobs). On the length of this longwall and on the part of the run (where the height of extraction was significantly reduced), there were difficulties in maintaining the roof and the correction of the position of the canopies, which was required due to the difficulty of parallelism with the floor bases. The two leg shields tended to set up with raised canopies in almost one line with legs. The results of the model calculations, drawings, and diagrams presented here are an attempt to find the reason for these events. 


\section{DESCRIPTION OF LONGWALL 124}

Longwall 124 was carried in the floor layer of the 510 seam south of the Morga Fault and east of the Brzęczkowice Fault. After selecting the top layer, the remaining thickness of Seam 510 in this region ranged from about $3.0 \mathrm{~m}$ to $6.5 \mathrm{~m}$. The seam was located at a depth of about $645-700 \mathrm{~m}$, with an inclination of about $6^{\circ}$ towards the southwest.

In the roof of Longwall 124 were gobs of the 510 seam's roof layers formed from sandstone layers, conglomerates, clay shales, and sandy slates. Seam 510 was located a distance of about $20-30 \mathrm{~m}$ above it. The floor was formed from a layer of shale.

Prior to the mining of the top layer of the seam, the roof had a compressive strength that ranged between 32-52 MPa, coal about $22 \mathrm{MPa}$, while the floor was about $31 \mathrm{MPa}$. The carried-out calculation of the gobs substitute strength conducted according to the GIG method developed as a result of the PROSAFECOAL 2007-2010 project [1] determined their value at slightly above $9 \mathrm{MPa}$, which is the average level of reconsolidation in the adopted classification (already close to weak $<8 \mathrm{MPa}$ ) [2].

In the area of Longwall 124 (up to $160 \mathrm{~m}$ above the floor layers of Seam 510), the roof layer of the seam was extracted directly above Longwall 124 and Seam 405/2 located at a distance of $170 \mathrm{~m}$. The seams located under the 510 seam have not been extracted yet.

The extraction of Longwall 124 was based on cave mining in the bilateral surroundings of the coal (in the floor layer) of up to $4.5 \mathrm{~m}$, leaving a carbon shelf in the longwall. Its task was to isolate the gobs from the working space and provide a roof load index of $g \geq 0.8$. For this purpose, the minimum thickness was calculated, which should range between 0.6-1.0 m depending on the longwall run-out section and support type (five types of supports were used in the longwall).

At the first stage of the mining process, the longwall was $130 \mathrm{~m}$ long (which was increased to $225 \mathrm{~m}$ after about $325 \mathrm{~m}$ ), and its run reached about $640 \mathrm{~m}$.

On some supports of the runway, the height of the longwall was significantly reduced in relation to the maximum possible $(4.5 \mathrm{~m})$ due to the variable carbon layer remaining to be selected, the carbon thickness of the floor layer, and the need to leave a protective carbon shelf. At longwall heights lower than about $3.4 \mathrm{~m}$, the shields were aligned with the raised canopy, and there were significant difficulties in correcting its position in order to ensure the correct geometry; i.e., to obtain parallelism between the canopies and the floor bases. Numerous damages were observed referring to the legs of the support cylinders and section shifters, which resulted in difficulties in maintaining the longwall and the need to replace the damaged elements. A broader description can be found in [3].

\section{SELECTED GEOMETRY MODELS OF SECTIONS IN LONGWALL 124}

On the basis of the ongoing observation and local vision carried out at the end of the longwall, characteristic cases of the geometry form of the OBUD-1 and OBUD-2 supports were determined on the sections of occurrence of difficulties during the liquidation.

It was found that, for each type of support, two cases of geometry models should be tested and analyzed for frequent heights in the front of the longwall (about $3.0 \mathrm{~m}$ and $3.5 \mathrm{~m}$ ). The geometric dimensions of the support indicated that, in order to obtain the underground effect of the almost linear arrangement of the caving shield and the canopy, the lemniscate bars of OBUD-1 and OBUD-2 must be located at the same height $(2.4 \mathrm{~m}$ and $2.7 \mathrm{~m}$, respectively, with a horizontal canopy), while the inclination angles should reach about $8^{\circ}$ and $12^{\circ}$ [4].

The identification of the layout of the support was based on the method and software for the geometry analysis and distribution of the forces in the two leg shield nodes used in the Department of Extraction Technologies and Mining Support of the Central Mining Institute [5]. Four models of geometry for the variants described above are shown in Figures 1-4. The results of the force calculations for these models were compared with the model where the support canopy and base are in horizontal position and the working height is $4.5 \mathrm{~m}$ (Figs. 5 and 6).

Figures 1-6 present the subsurface representing a schematic distribution of the surface pressures during rock mass pressure impacting on the roof support and for the assumed coefficient of the friction between steel and rock of $\mu=0.3$. 


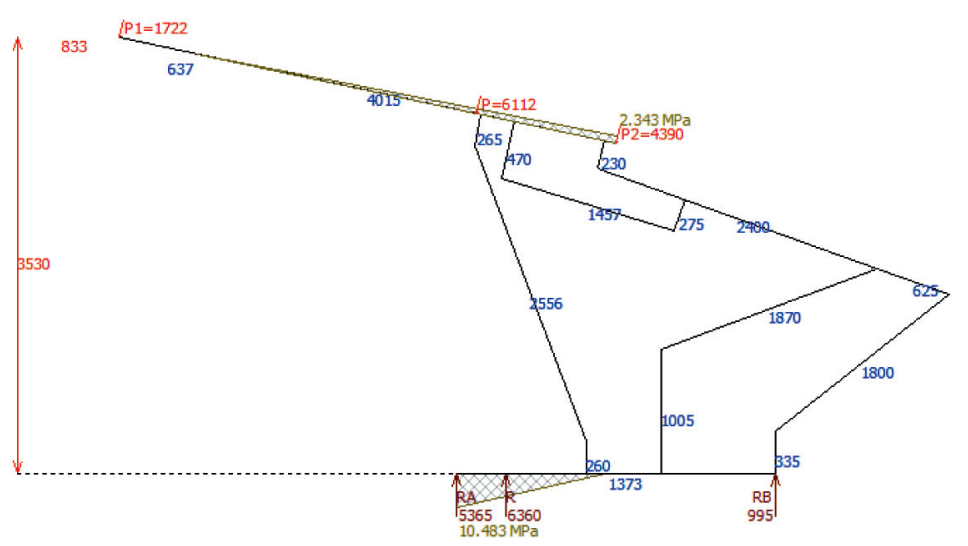

Fig. 1. Model $1-O B U D-1$, excavation height about $3.5 \mathrm{~m}$, canopy raised at angle of $12^{\circ}$

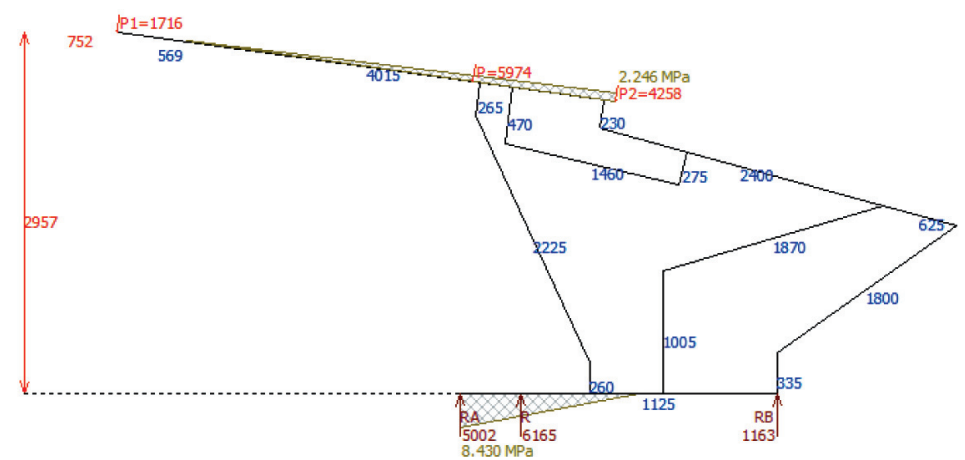

Fig. 2. Model $2-O B U D-1$, excavation height about $3.0 \mathrm{~m}$, canopy raised at angle of $8^{\circ}$

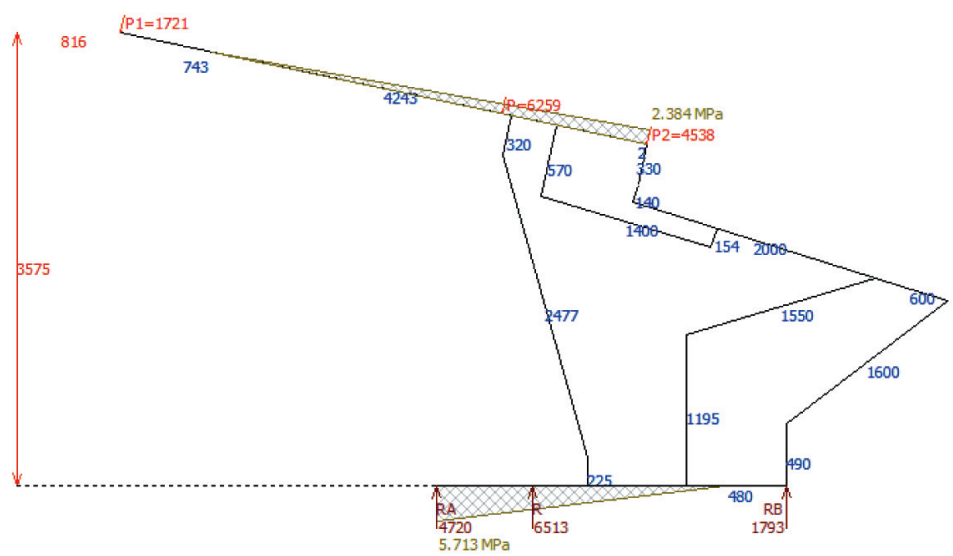

Fig. 3. Model $3-O B U D-2$, excavation height about $3.5 \mathrm{~m}$, canopy raised at angle of $12^{\circ}$

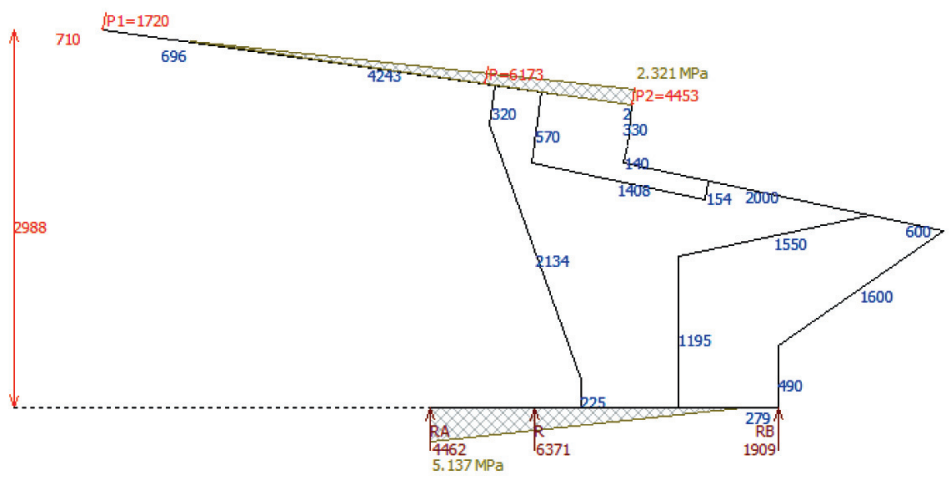

Fig. 4. Model 4-OBUD-2, excavation height about $3.0 \mathrm{~m}$, canopy raised at angle of $8^{\circ}$ 


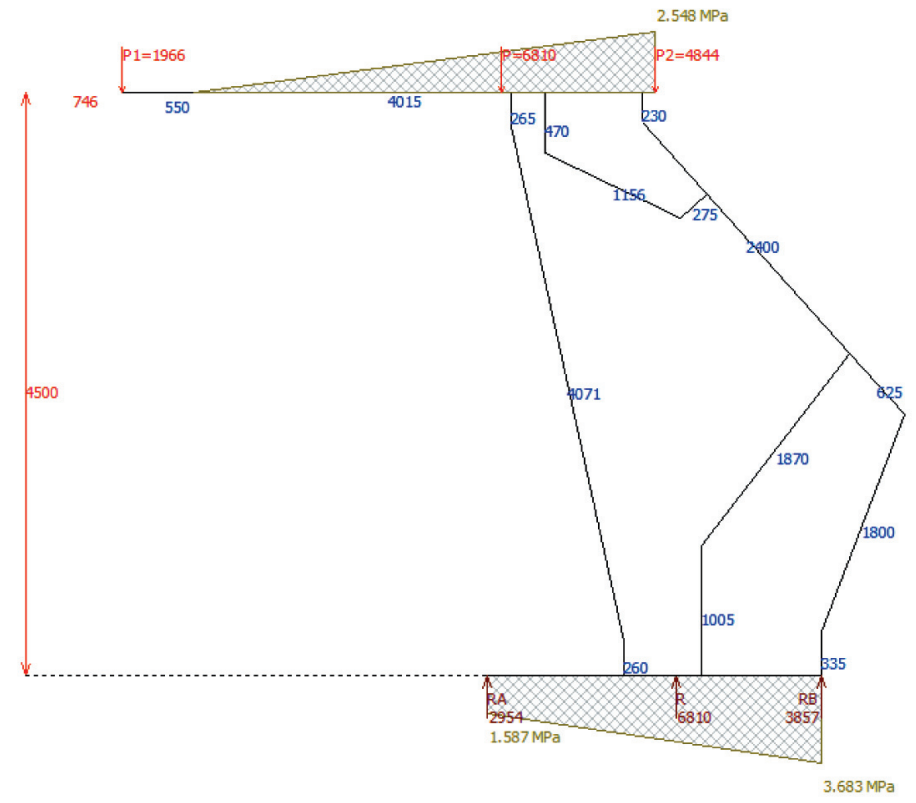

Fig. 5. Model $5-$ OBUD-1, excavation height $4.5 \mathrm{~m}$, horizontal canopy (angle $0^{\circ}$ )

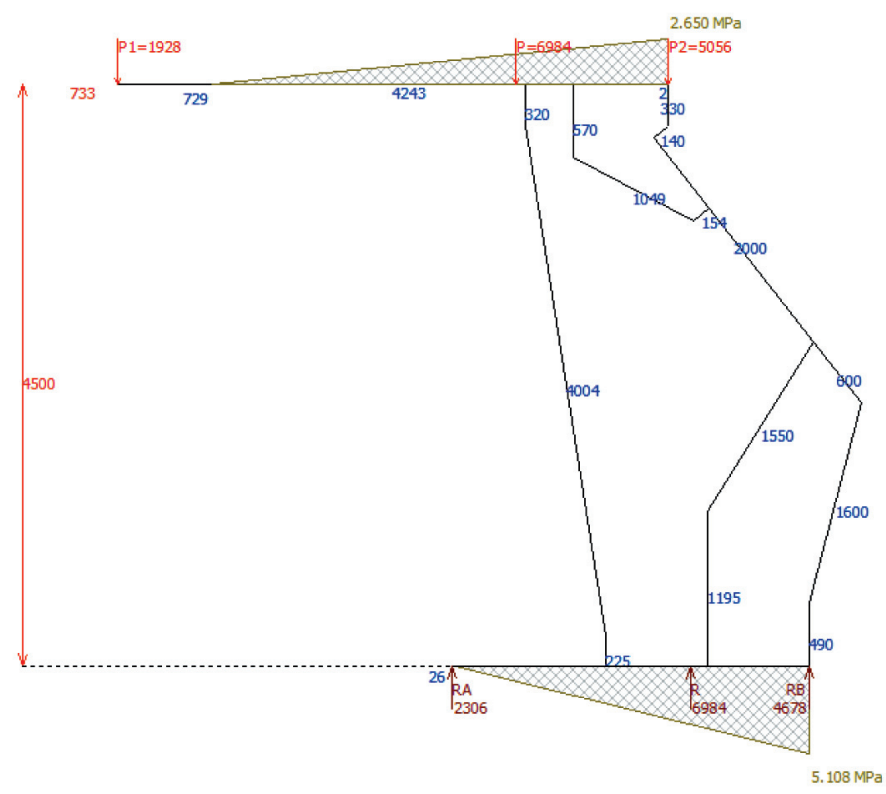

Fig. 6. Model 6-OBUD-2, excavation height $4.5 \mathrm{~m}$, horizontal canopy (angle $0^{\circ}$ )

4. ANALYTICAL CALCULATION OF FORCE IN NODES OF SUPPORT WITH DIFFERENT LOAD OF CAVING SHIELD AND INCLINATION OF CANOPY

\subsection{Section load at low working heights}

The research team decided to include a simulation of the possibility of different load values impacting the caving shields in the calculations due to the caving debris that laid on the shields. The following variants of the load generated by the rock mass and impacting on OBUD-1 and OBUD-2 have been considered, as these two types of supports are often used during the analysis of the structure or operation of the powered roof support:

- no load impacting on the caving shield;

- load of $100 \mathrm{kN} / \mathrm{m}^{2}$ - this value of the caving shield load was assumed in German mining and resulted from the stabilization condition of the joint of the canopy and caving shield [6] (this load corresponds to the weight of a $4.0 \mathrm{~m}$ high column), which was confirmed during the trial tests;

- point load of the caving shield with vertical force of $600 \mathrm{kN}$ located in the middle of the length of the caving shield, which is used in the analyses performed by the constructors of the support. 
The research team decided to compare the values of these loads with the results of other calculations; in this case, those carried out according to the method presented in [7].

Taking into account the dimensions of the OBUD-1 and OBUD-2 supports, the calculations performed showed that a load impacting on the caving shield with a relatively wide variability of approx. $300-950 \mathrm{kN}$ can be expected depending on the assumed parameters, with the ratio of the load from the caving shield to the load of the canopy, while the support height decreases (depending on the conditions considered) may vary from approximately $41 \%$ to $73 \%$ for OBUD- 1 and from approximately $30 \%$ to $58 \%$ for OBUD -2 .

Therefore, the considered values of the loads are to a large extent comparable; nevertheless, they should be assessed with a certain approximation because the interpreted calculation scheme did not consider the loads for the inclined canopy.

\subsection{Forces in structural nodes of powered roof supports}

The values of the forces occurring in its structural nodes affecting the values of stresses and determining the durability of the whole structure or its specific elements fluctuate along with the change of the support's resistance.
In order to carry out the analysis of the forces in the structural nodes, a computational model was used that allowed for the calculation of the geometry and forces in the powered roof support according to the diagrams shown in Figures 7 and 8.

The computational model of a powered support developed in the Department of Extraction Technologies and Mining Support of GIG (included in the form of a computer program) allows for an analysis of its support in the function of many different parameters occurring during operation [5]. Calculations can be carried out for all types of supports used in Polish hard coal mines; i.e., backfilling or roof caving systems. The friction forces between the support and rock mass are included, which arise during the horizontal movement of the canopy on the lemniscate curve when the working height is changed. The actual conditions show that these forces should be taken into account in the static calculations carried out for the support, as they generate internal stresses in the elements and affect the stability (especially in the setting phase).

Calculations can be carried out for the parallel and inclined canopy with respect to the floor of the longwall excavation, and the direction of the external forces is perpendicular to the canopy. The dependencies are calculated as they are for rigid beams.

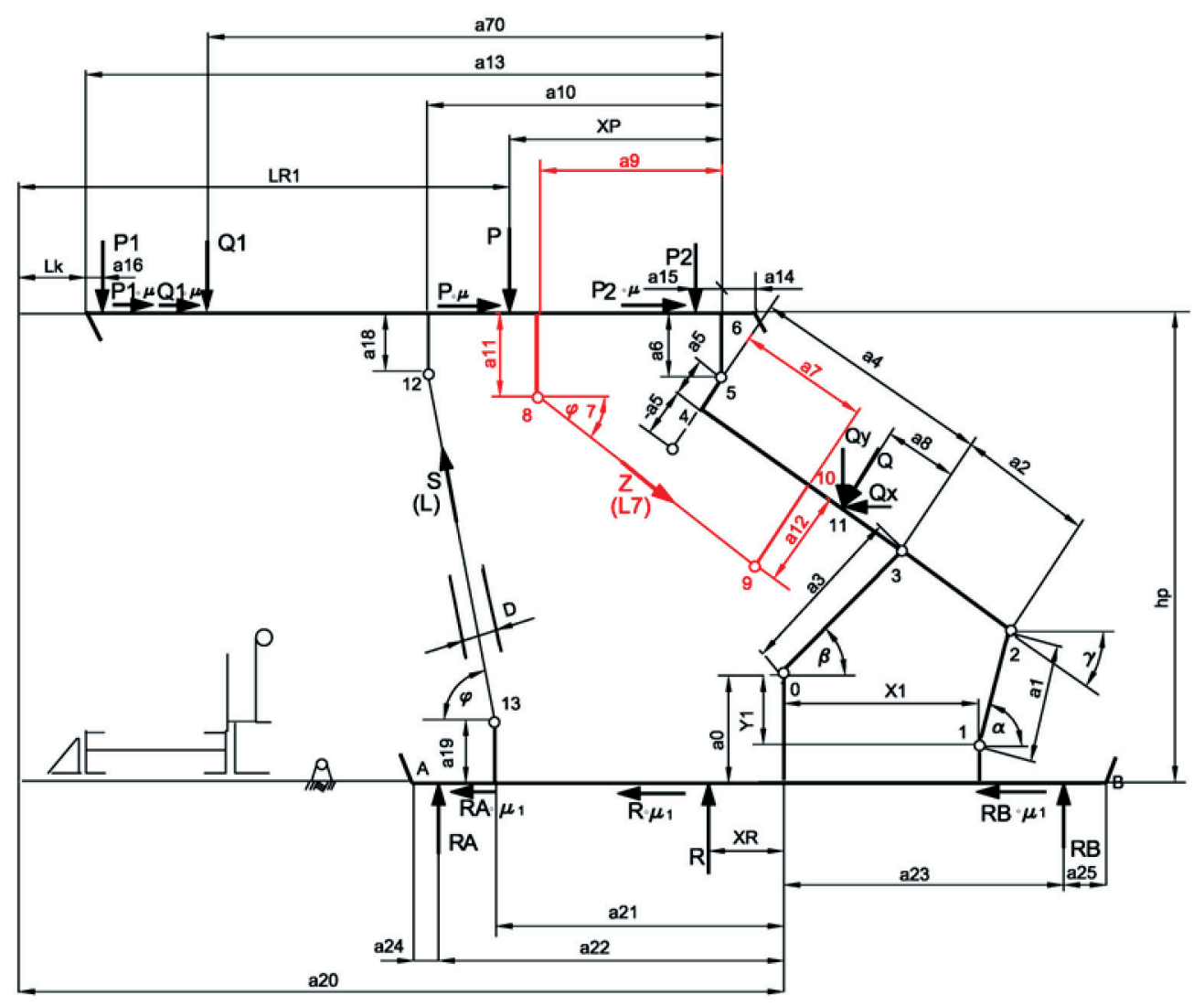

Fig. 7. Geometry scheme of powered roof support 


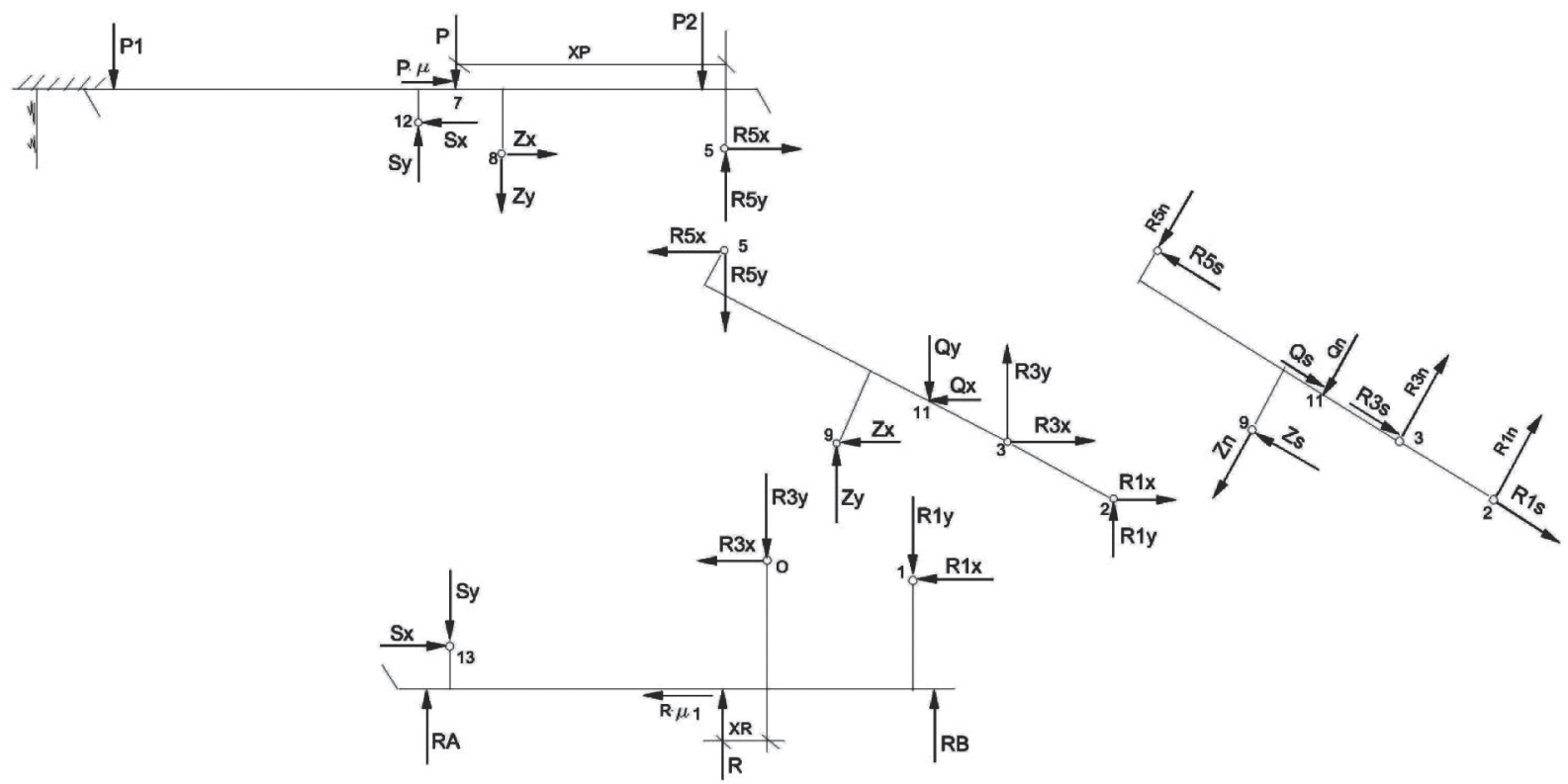

Fig. 8. Distribution of forces in nodes of powered roof support

Calculations of values can be carried out for forces:

- caused by the pressure of the rock mass impacting on the canopy (simulating the occurrence of additional external forces) and the pressure of the caving rocks on the caving shield, with the given load bearing capacity of the legs;

- occurring during the expansion of the roof support, with the initial load-bearing capacity resulting from the supply pressure of the legs, taking into account a change in the return of friction forces in this case.

The developed calculation model makes it possible to analyze the friction forces and compare them to the direction of the friction force resulting from the course of the lemniscate curve when the support's height is changed assuming the unchanged direction of the friction force when changing the height of the support.

The conclusions resulting from underground observations and the obtained geometry of the supports for the models shown in Figures 1-4 caused that particular attention was paid to the calculation of the following forces: R5x, R5y, R5n, and R5s, as the components of the R5 force. The R5 force is located at the joint between canopy and caving shield so has the decisive influence considering proper support geometry.

Calculations of the value of this force were made depending on the height of the working support for each of them and referred to these angles of the canopy: $0^{\circ}, 8^{\circ}$, and $12^{\circ}$ and for three load variants.

The results are presented in Tables 1 and 2 and in Figures 9 and 10.

Table 1

Values of force R5 [kN] in node of canopy's joint with caving shield for OBUD-1

\begin{tabular}{|c|c|c|c|c|c|c|c|c|c|}
\hline \multirow{4}{*}{$\begin{array}{c}\text { Height of } \\
\text { support } \\
\text { (for lemnis- } \\
\text { cate system) } \\
\text { [m] }\end{array}$} & \multicolumn{9}{|c|}{ Inclination of canopy } \\
\hline & \multicolumn{3}{|c|}{$0^{\circ}$} & \multicolumn{3}{|c|}{$8^{\circ}$} & \multicolumn{3}{|c|}{$12^{\circ}$} \\
\hline & \multicolumn{3}{|c|}{ load of caving shield } & \multicolumn{3}{|c|}{ load of caving shield } & \multicolumn{3}{|c|}{ load of caving shield } \\
\hline & $0 \mathrm{kN}$ & $100 \mathrm{kN} / \mathrm{m}^{2}$ & $600 \mathrm{kN}$ & $0 \mathrm{kN}$ & $100 \mathrm{kN} / \mathrm{m}^{2}$ & $600 \mathrm{kN}$ & $0 \mathrm{kN}$ & $100 \mathrm{kN} / \mathrm{m}^{2}$ & $600 \mathrm{kN}$ \\
\hline 2.4 & 1276 & 1394 & 1454 & 1975 & 2046 & 2084 & 2302 & 2353 & 2381 \\
\hline 2.7 & 816 & 944 & 1025 & 1587 & 1661 & 1708 & 1946 & 1998 & 2033 \\
\hline 2.9 & 563 & 699 & 799 & 1371 & 1444 & 1499 & 1747 & 1797 & 1838 \\
\hline 3.3 & 168 & 335 & 497 & 1027 & 1092 & 1167 & 1428 & 1471 & 1523 \\
\hline 3.7 & 115 & 203 & 403 & 775 & 829 & 930 & 1194 & 1226 & 1293 \\
\hline 4.1 & 332 & 321 & 449 & 584 & 625 & 761 & 1014 & 1038 & 1124 \\
\hline 4.5 & 554 & 525 & 548 & 408 & 440 & 633 & 851 & 872 & 997 \\
\hline
\end{tabular}


Table 2

Values of force $\mathrm{R5}$ [kN] in node of canopy's joint with caving support for OBUD-2

\begin{tabular}{|c|c|c|c|c|c|c|c|c|c|}
\hline \multirow{4}{*}{$\begin{array}{c}\text { Height of } \\
\text { support } \\
\text { (for lemnis- } \\
\text { cate system) } \\
\text { [m] }\end{array}$} & \multicolumn{9}{|c|}{ Inclination of canopy } \\
\hline & \multicolumn{3}{|c|}{$\mathbf{0}^{\circ}$} & \multicolumn{3}{|c|}{$8^{\circ}$} & \multicolumn{3}{|c|}{$12^{\circ}$} \\
\hline & \multicolumn{3}{|c|}{ load of caving shield } & \multicolumn{3}{|c|}{ load of caving shield } & \multicolumn{3}{|c|}{ load of caving shield } \\
\hline & $0 \mathrm{kN}$ & $100 \mathrm{kN} / \mathrm{m}^{2}$ & $600 \mathrm{kN}$ & $0 \mathrm{kN}$ & $100 \mathrm{kN} / \mathrm{m}^{2}$ & $600 \mathrm{kN}$ & $0 \mathbf{~ k N}$ & $100 \mathrm{kN} / \mathrm{m}^{2}$ & $600 \mathrm{kN}$ \\
\hline 2.4 & 635 & 765 & 857 & 1370 & 1443 & 1503 & 1707 & 1761 & 1807 \\
\hline 2.7 & 175 & 345 & 499 & 987 & 1067 & 1147 & 1358 & 1417 & 1476 \\
\hline 2.9 & 72 & 216 & 394 & 776 & 858 & 955 & 1164 & 1222 & 1292 \\
\hline 3.3 & 439 & 416 & 499 & 454 & 532 & 675 & 865 & 913 & 1007 \\
\hline 3.7 & 668 & 639 & 680 & 244 & 309 & 520 & 669 & 700 & 821 \\
\hline 4.1 & 816 & 795 & 810 & 109 & 151 & 446 & 544 & 558 & 707 \\
\hline 4.5 & 1030 & 1024 & 932 & 30 & 30 & 396 & 424 & 427 & 643 \\
\hline
\end{tabular}

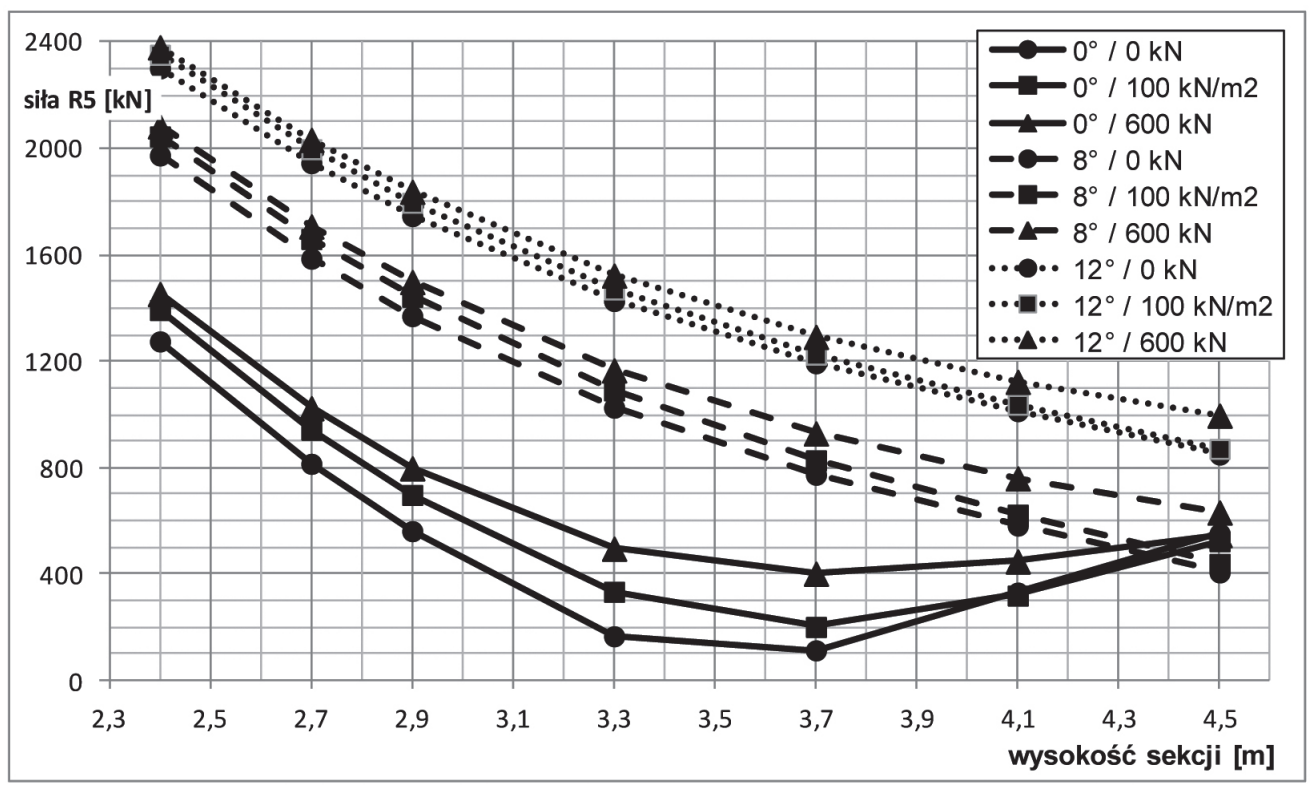

Fig. 9. Values of force R5 [kN] in node of canopy's joint with caving shield for OBUD-1

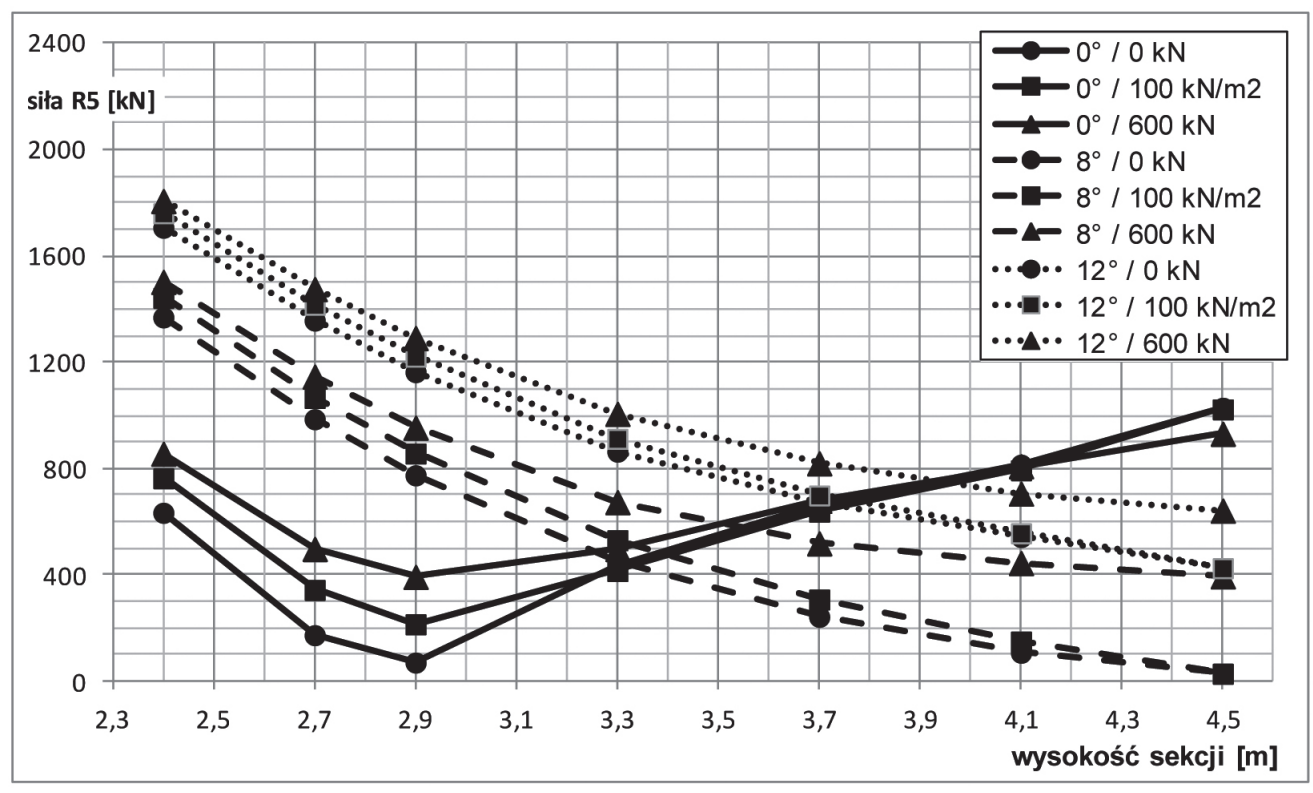

Fig. 10. Values of force R5 [kN] in node of canopy's joint with caving shield for OBUD-2 


\section{SUMMARY}

On the basis of the analysis of the defined calculation models of the OBUD-1 and OBUD-2 support and variant load calculations, it can be stated that the force values in the construction nodes of these sections may differ significantly from the model typically adopted in the operation and maintenance manual for the maximum working and horizontal height.

The changes of the force value in the joint of the canopy with the caving shield (R5 in Fig. 8) based on the presented calculations and diagrams depend primarily on the particular form of the kinematics (geometric dimensions) of the support (in this case, OBUD-1 or OBUD-2), then from the inclination between the canopy and the floor base as well as the load impacting on the caving shield of the support.

In the case of the height of the lemniscate system of OBUD-1 and OBUD-2 $(2.4 \mathrm{~m}$ and $2.7 \mathrm{~m}$, respectively) and the angles of their canopies $\left(8^{\circ}\right.$ and $12^{\circ}$, respectively), the values of force are clearly higher than the values calculated for the height of $4.5 \mathrm{~m}$ with a horizontal canopy. In the case of OBUD-1, they can be increased by up to 4.3 times, while they can be increased by about 1.8 times in the case of OBUD-2. Additional calculations have also shown that, when expanding the support, these forces can still increase significantly.

When laying the canopy and caving shield in almost one line, the inclination of Force R5 was often directed almost in the direction of Force component R5s (Fig. 8) and the line of the tilt cylinder. Considering the fact that the support was characterized by a maximum power of $588 \mathrm{kN}$ under the piston or $703 \mathrm{kN}$ above the piston, its changes could have a negligible effect on the possibility of correcting the position of the canopy. Under such conditions, the operation of the tilt cylinder was ineffective or even impossible, and the sections tended to form one plane from the canopy and the caving shield up to the position blocked by the stops and/or the maximum extension of the cylinders.

In the conditions of Longwall 124, this caused that the mining process was conducted while the canopy was raised and the roof was supported in a linear way, which led to the destruction of its structure and precipitation. In this particular case, the interruption of the continuity of the protective carbon shelf left in the roof of the excavation resulted in the roof falls and significant difficulties during operation.

It can be assumed that, in the case of maintaining these supports in a similar configuration but under a natural roof (where a carbon shelf is not required for insulating a weak layer in the direct roof; e.g., goafs), this intensity of falls may occur if there is a sufficient mechanical strength of the roof; nevertheless, the conditions for its "cutting" will still prevail as a result of the difficulties in correcting the positions of the canopies.

The diagrams presented in Figures 9 and 10 indicate that, for OBUD-1, the increase in Force R5 in the node joining the canopy with the caving shield is larger than the scale of the increase observed for OBUD-2; therefore, unfavorable phenomena may occur for the other higher support's heights than for OBUD-2. Practice has shown that the difficulties in Longwall 124 subsided while maintaining working heights greater than approximately $3.5 \mathrm{~m}$.

The operation of the support with the wrong geometry (Figs. 1-4) also causes increased pressure in the front of the floor base, which can cause additional difficulties in the extraction process of the longwall in the case of working on weak floors.

The fact that the excessive accumulation of caving debris on the caving shields resulting from the small angles of their inclination and large surfaces of the covers (caused by relatively large lengths) can occur is another instance of unfavorable conditions.

The calculations carried out on the models show that, for OBUD-1 for Models 1 and 2 (Figs. 1, 2), these angles for longwall heights of approximately 3.5 and $3.0 \mathrm{~m}$ reached $19.8^{\circ}$ and $15.3^{\circ}$, respectively. For comparison, with the correct support geometry and working heights of $3.0,3.5$, and $4.5 \mathrm{~m}$, these angles obtain the following values: $24.1^{\circ}, 31.2^{\circ}$, and $48.1^{\circ}$, respectively (Fig. 11). For OBUD 2 for Models 3 and 4 (Figs. 3, 4), the inclination angles of the caving shield towards the bottom of the excavation reached $17.4^{\circ}$ and $11.9^{\circ}$, respectively. Similarly as before - for comparison, with the correct support geometry and working heights of $3.0,3.5$, and $4.5 \mathrm{~m}$, these angles obtain the following values: $22.4^{\circ}, 27.5^{\circ}$, and $51.9^{\circ}$, respectively (Fig. 11).

The small values of the angle of inclination of the caving shield at low working heights of the support may have a significant impact on the load of the supports and their proper cooperation with the rock mass aimed at ensuring the stability of the longwall working. Angles of inclination of the caving shield lower than about $30^{\circ}$ are often too small to overcome the frictional force forming on the contact of the caving shield with the loose rocks coming from the caving [8] in the case of the possibility of slipping. 


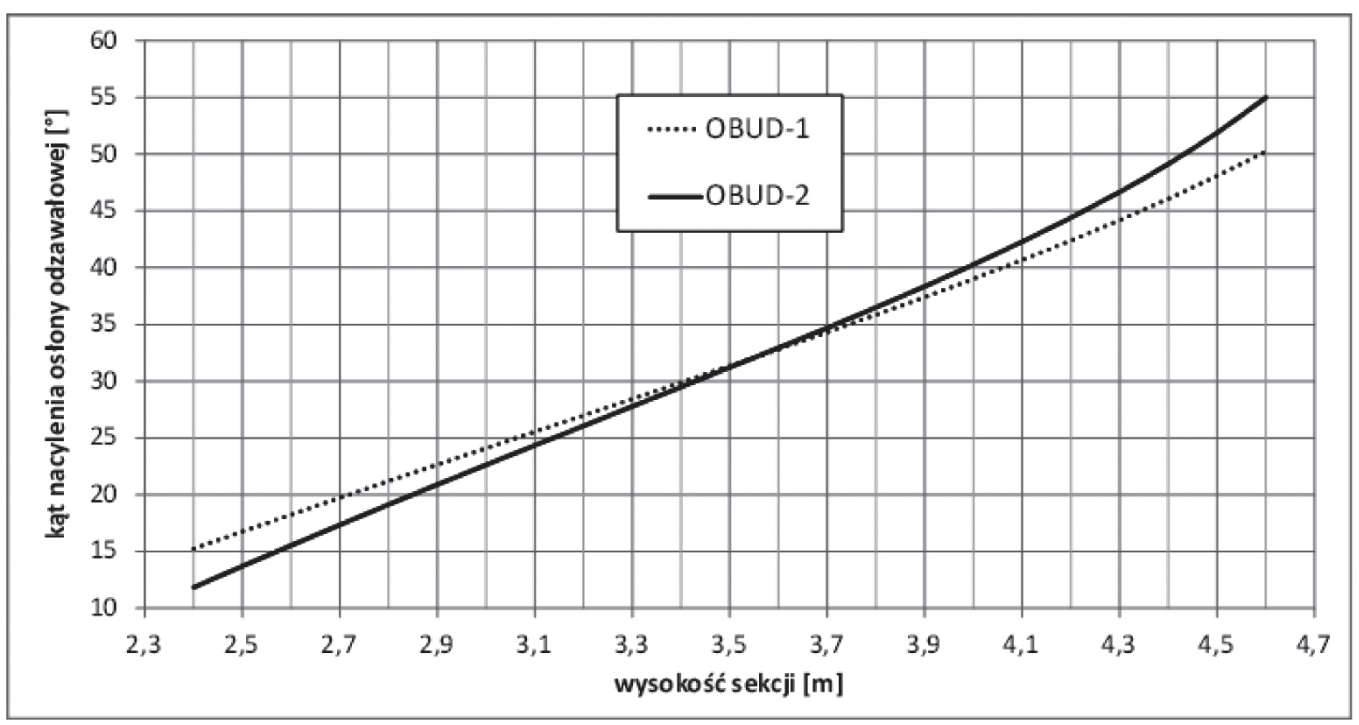

Fig. 11. Inclination angles of the caving shield in the OBUD-1 and OBUD-2 at the correct geometry

This leads to the excessive accumulation of caving debris on the section, which, in combination with the very large surface of the shield supports resulting from their length - determined mainly by the wide range of the working height of the section (2.4-4.5 m), causes both an additional significant load on the analyzed supports as well as an increase in the forces in the structural nodes.

In the case of low support heights and incorrect geometry (Models 1-4 - Figs. 1-4), load impacting on the caving shield may lead to a reduction of loadbearing capacity of up to $17.5 \%$ in relation to the conditions specified in the operation and maintenance manual for heights reaching $4.5 \mathrm{~m}$ with a horizontal canopy.

\section{CONCLUSION}

Based on the observations, calculations, and analyses carried out, the following conclusions can be made:

1. The main reason for the difficulties in ensuring the stability of the Longwall 124 excavation (formation of roof falls) in the case of maintaining the OBUD-1 and OBUD-2 supports in the lower range of the working heights was the improper geometry of the support, consisting of the formation of almost one plane between the caving shield and the canopy. In the specific case of Longwall 124, this caused a linear support of the roof resulting in damage, consequently leading to the breaking of the coal shelf and falling of the goafs.
2. The incorrect geometry of the support was the result of a significant increase in the forces in the canopy's joint with the caving shield, which could practically prevent the effective correction of the location of the canopy by means of a tilt cylinder.

3. In the case of the OBUD-1 and OBUD-2 supports, the values of the forces in the joint of the canopy and the caving shield depend in the analyzed cases on the low working heights, first of all from the geometric dimensions of the support, then from the angle of inclination between the canopy and the floor base and from the load impacting on the caving shield of the support.

4. The calculations indicate that the discussed difficulties for the analyzed supports are mainly related to the low heights of operation. Practice has shown that the difficulties in Longwall 124 have subsided while maintaining working heights greater than approximately $3.5 \mathrm{~m}$.

5. The work of the section with the wrong geometry referred to in this article leads to very high-pressure values to be generated in the front of the floor base, which may also cause additional difficulties in extracting the longwall (even when working on weak floors).

\section{Acknowledgement}

This article includes the results of work carried out within the framework of the PRASS III project, entitled "Productivity and Safety of Shield Support". This project is co-financed by the Research Fund for Coal and Steel (Project 752504) and the Ministry of Science and Higher Education. 


\section{References}

[1] Masny W., Prusek S., Walentek A.: Pomiary konwergencji oraz obciążenia działającego na obudowe wyrobisk korytarzowych zlokalizowanych pod zrobami zawałowymi wraz $z$ metoda oceny ich rekonsolidacji, Międzynarodowa Konferencja Naukowo-Techniczna "Górnicze Zagrożenia Naturalne", "Prace Naukowe GIG. Górnictwo i Środowisko" 2011 4/2: 297-304.

[2] Płonka M. et al.: Wykonanie pracy naukowo-badawczej określajacej możliwości stosowania, upodatnienia $i$ warunki wspótpracy sekcji obudów zmechanizowanych różnych typów dla ściany 124 w pokładzie 510, poz. $500 \mathrm{~m}$ w KHW SA KWK Mystowice-Wesoła, Praca badawczo-usługowa GIG o symbolu 581 07936-152, GIG, Katowice 2016 [unpublished].

[3] Rajwa S., Prusek S., Szuścik J., Gąska R.: Prowadzenie ściany pod gruzowiskiem zawałowym w warunkach zmiennej grubości pozostawionej warstwy przyspagowej, "Przegląd Górniczy" 2017, 6: 33-37.

[4] Płonka M. et al.: Opracowanie dotyczące wykonania oceny wspótpracy z górotworem sekcji obudowy zmechanizowanej $w$ zakresie roboczym tej obudowy, Praca badawczo-usługowa GIG o symbolu 581 35956-152, GIG, Katowice 2016 [unpublished].
[5] Płonka M., Rajwa S.: Podporność i rozkład sił w węzłach sekcji obudowy zmechanizowanej, "Wiadomości Górnicze" 2009, 10: 611-616.

[6] Irresberger H., Gräwe F., Migenda P.: Zmechanizowane obudowy ścianowe, Wydawnictwo Tiefenbach Polska Sp. z o.o., Piekary Ślaskie 2003.

[7] Losiak S., Ptak J.: Wpływ gruzowiska zawałowego na ostonę odzawatowa i zachowanie się sekcji lemniskatowej obudowy ścianowej, "Mechanizacja i automatyzacja górnictwa" 2010, 3: 35-41.

[8] Frith R.C.: A holistic examination of the load rating design of longwall shields after more than half a century of mechanised longwall mining, "International Journal of Mining Sciences and Technology" 2015, 25: 687-706.

MAREK PŁONKA, Ph.D., Eng. SYLWESTER RAJWA, Ph.D., Eng.

Laboratory of Support Selection for Extraction Mine Workings GIG Central Mining Institute pl. Gwarków 1, 40-166 Katowice, Poland \{mplonka,srajwa\}@gig.eu 
MAREK PŁONKA

SYLWESTER RAJWA

\title{
Utrudnienia w prowadzeniu sekcji obudowy zmechanizowanej obserwowane podczas pracy w dolnym zakresie jej wysokości roboczej
}

\begin{abstract}
W przypadku stosowania obudowy zmechanizowanej, która charakteryzuje się szerokim zakresem wysokości roboczych, $w$ ostatnim czasie kilkakrotnie obserwowano istotne utrudnienia utrzymania stropu ścian podczas eksploatacji w przedziale niskich wysokości pracy sekcji. Utrudnienia te napotykano także w sytuacjach, gdy wyliczony wskaźnik nośności stropu g osiagat korzystne wartości. Zjawiska te występowaty najczęściej podczas eksploatacji pod zrobami zawałowymi i przy utrzymywaniu ochronnej stropowej pótki weglowej o wymaganej grubości. $W$ artykule przedstawiono obliczenia $i$ analizy zmierzające do wyjaśnienia i omówienia tych sytuacji.
\end{abstract}

Słowa kluczowe: obudowa zmechanizowana, podporność, sity, ocena

\section{WPROWADZENIE}

Ze względu na warunki projektowanych eksploatacji wprowadzane do użytkowania w poprzednich latach obudowy zmechanizowane wyposażane są w stojaki o dużych średnicach, umożliwiające rozwijanie znacznych sił. Dąży się do uzyskania szerokich przedziałów rozpiętości wysokości roboczych sekcji, ponieważ kopalnie pragną dysponować uniwersalnymi obudowami, które można stosować w pokładach o różnych miąższościach. W rezultacie powstają konstrukcje charakteryzujące się większymi rozmiarami i podpornościami $\mathrm{w}$ porównaniu $\mathrm{z}$ dotychczas użytkowanymi, co w naturalny sposób może wywoływać problemy i komplikacje, jakich wcześniej nie obserwowano. Zwiększenie rozmiarów sekcji obudowy zmechanizowanej skutkuje bowiem większymi gabarytami wyrobiska, wywołuje większe obciążenie ze strony górotworu i generuje większe siły w węzłach konstrukcji. W związku z taką sytuacją podstawowe znaczenie ma zapewnienie odpowiednich parametrów wytrzymałościowych obudowy oraz dobry projekt jej kinematyki, co w rezultacie powinno zapewnić jej poprawną współpracę z górotworem, gwarantującą spełnienie wymagań wynikających $\mathrm{z}$ warunków geologiczno-górniczych przyszłych rejonów eksploatacji.

W artykule przedstawiono wyniki obliczeń i analiz związanych $\mathrm{z}$ dwoma typami liniowych obudów zmechanizowanych o zakresie wysokości konstrukcyjnej od 2,4 m do 4,6 m, o średnicach wewnętrznych pierwszego stopnia stojaków $320 \mathrm{~mm}$, nazywanych dalej OBUD-1 i OBUD-2, które zostały zastosowane w Kopalni Węgla Kamiennego Mysłowice-Wesoła, w warstwie przyspągowej pokładu $510 \mathrm{w}$ ścianie 124, prowadzonej pod zrobami warstwy górnej. Na odcinku długości tej ściany i na fragmencie wybiegu, na którym znacznie obniżono wysokość eksploatacji, wystąiły istotne trudności w utrzymaniu stropu oraz z korekcją położenia stropnic, która była wymagana ze względu na trudności zachowania ich równoległości względem spągnic. Sekcje miały tendencje do ustawiania się z uniesionymi stropnicami w niemal jednej linii z osłonami odzawałowymi. Zamieszczone rezultaty obliczeń modelowych, rysunki i wykresy stanowią próbę znalezienia przyczyny tej sytuacji. 


\section{CHARAKTERYSTYKA ŚCIANY 124}

Ściana 124 prowadzona była w warstwie przyspągowej pokładu 510, na południe od Uskoku Morgi i na wschód od Uskoku Brzęczkowickiego. Pozostała miąższość pokładu $510 \mathrm{w}$ tym rejonie, po wybraniu warstwy górnej wynosiła od około $3 \mathrm{~m}$ do $6,5 \mathrm{~m}$. Pokład zalegał na głębokości 645-700 m, przy nachyleniu około $6^{\circ} \mathrm{w}$ kierunku południowo-zachodnim.

W pułapie ściany 124 występowały zroby zawałowe warstwy przystropowej pokładu 510, powstałe z piaskowców, zlepieńców, łupków ilastych i łupków piaszczystych, powyżej których w odległości 20-30 m zalegał pokład 501. Spąg stanowiła warstwa łupku ilastego.

Przed wybraniem warstwy górnej pokładu strop cechował się wytrzymałością na ściskanie z zakresu 32-52 MPa, węgiel około $22 \mathrm{MPa}$, natomiast spąg około $31 \mathrm{MPa}$. Przeprowadzone obliczenia wytrzymałości zastępczej zrobów, wykonane według metody GIG powstałej w wyniku realizacji projektu PROSAFECOAL 2007-2010 [1], określiły jej wartość na nieco powyżej $9 \mathrm{MPa}$, co w przyjętej klasyfikacji oznacza średni stopień rekonsolidacji (bliski już jednak słabemu $<8 \mathrm{MPa}$ ) [2].

W rejonie pola ściany 124 , w odległości do $160 \mathrm{~m}$ nad warstwą przyspagową pokładu 510, eksploatowano warstwę przystropową tego pokładu, bezpośrednio nad ścianą 124 oraz pokład 405/2 oddalony o około $170 \mathrm{~m}$. Poniżej pokładu 510 węgla jeszcze nie eksploatowano.

Ścianę 124 prowadzono z zawałem stropu, w obustronnym otoczeniu calizną węglową ( $w$ warstwie przyspagowej), na wysokość do $4,5 \mathrm{~m}, \mathrm{z}$ pozostawianiem półki węglowej w pułapie ściany, której zadaniem były izolacja zrobów od przestrzeni roboczej oraz zapewnienie wskaźnika nośności stropu $g \geq 0,8$. W tym celu wyliczono minimalną jej grubość, która powinna wynosić $0,6-1,0 \mathrm{~m}$, w zależności od odcinka wybiegu ściany oraz typu sekcji (łącznie w ścianie pracowało pięć typów sekcji).

Ściana rozpoczęła bieg z długością $130 \mathrm{~m}$, która po około $325 \mathrm{~m}$ została zwiększona do $225 \mathrm{~m}$, a jej wybieg osiągnął około $640 \mathrm{~m}$.

Ze względu na pozostałą do wybrania ścianę 124 zmienną grubość węgla warstwy przyspagowej i konieczność pozostawiania ochronnej półki węglowej, na niektórych odcinkach wybiegu wysokość ściany była znacznie obniżana w stosunku do możliwej maksymalnej (4,5 m). Przy wysokościach ściany niższych od około 3,4 m sekcje ustawiały się z podniesioną ku górze stropnicą i występowały istotne trudności z korekcją jej położenia w celu zapewnienia poprawnej geometrii, tj. uzyskania równoległości pomiędzy stropnicami i spągnicami. Notowane były liczne uszkodzenia między innymi stojaków sekcji, siłowników podpory i przesuwników sekcji, co skutkowało trudnościami w prowadzeniu ściany i koniecznością wymiany uszkodzonych elementów. Szerszy opis przypadku przedstawiono $\mathrm{w}[3]$.

\section{WYTYPOWANE MODELE GEOMETRII SEKCJI LINIOWYCH W ŚCIANIE 124}

$\mathrm{Na}$ podstawie przeprowadzanych podczas biegu ściany bieżących obserwacji oraz wizji lokalnej dokonanej po zakończeniu jej biegu, w czasie likwidacji określono charakterystyczne przypadki postaci geometrii sekcji OBUD-1 i OBUD-2 na odcinkach występowania utrudnień.

Uznano, że dla każdego z typów sekcji liniowych należy zbadać dwa przypadki modeli geometrii, dla często występujących wysokości w czole ściany około 3,0 m i 3,5 m. Wymiary geometryczne sekcji wskazywały, że dla uzyskania obserwowanego pod ziemią efektu niemal liniowego ułożenia stropnicy i osłony odzawałowej, układy lemniskatowe sekcji OBUD-1 i OBUD-2 muszą być wtedy usytuowane jak przy pracy na wysokości odpowiednio 2,4 m i 2,7 m (ze stropnicą poziomą), natomiast kąty nachylenia stropnic wynosić powinny około $8^{\circ}$ i $12^{\circ}[4]$.

Dla identyfikacji ułożenia sekcji posłużono się stosowaną w Zakładzie Technologii Eksploatacji i Obudów Górniczych GIG metodą i oprogramowaniem do analizy geometrii i rozkładu sił w węzłach sekcji [5], a cztery modele geometrii sekcji, dla opisanych wyżej wariantów, przedstawiono na rysunkach 1-4. Wyniki obliczeń sił w węzłach konstrukcyjnych sekcji postanowiono porównać z obliczeniami dla postaci geometrii prezentowanych zwykle w DTR, tj. dla maksymalnej wysokości roboczej, która dla analizowanych sekcji wynosi $4,5 \mathrm{~m}$ przy poziomym ułożeniu stropnicy i spągnicy, co przedstawiają rysunki 5 i 6 .

$\mathrm{Na}$ rysunkach 1-6 powierzchnie pokratkowane przedstawiają schematyczny rozkład nacisków powierzchniowych podczas nacisku górotworu na obudowę i dla założonego współczynnika tarcia między stalą a skałą o wartości $\mu=0,3$. 


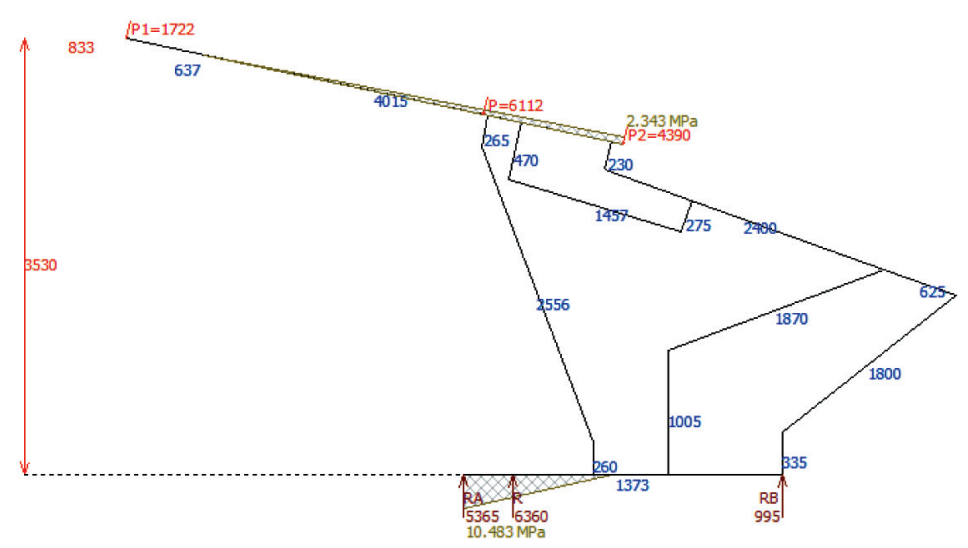

Rys. 1. Model 1, sekcja OBUD-1, wysokość wyrobiska około 3,5 m, stropnica podniesiona pod kątem $12^{\circ}$

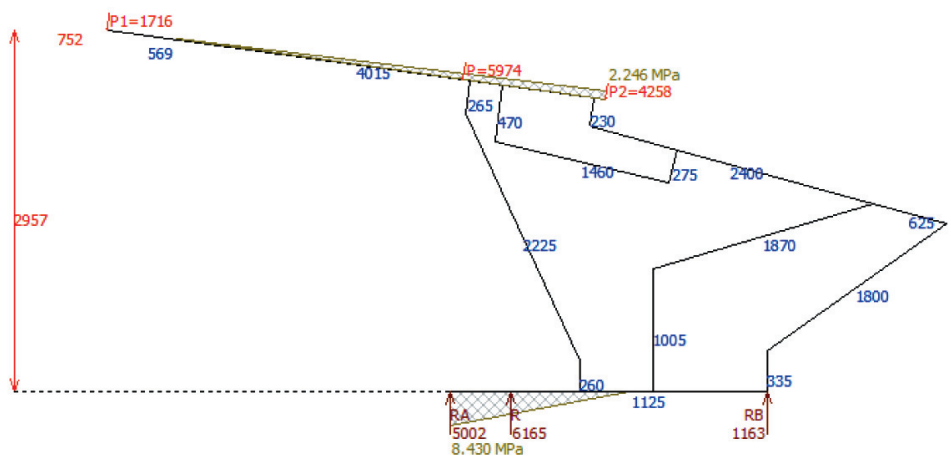

Rys. 2. Model 2, sekcja OBUD-1, wysokość wyrobiska około 3,0 m, stropnica podniesiona pod katem $8^{\circ}$

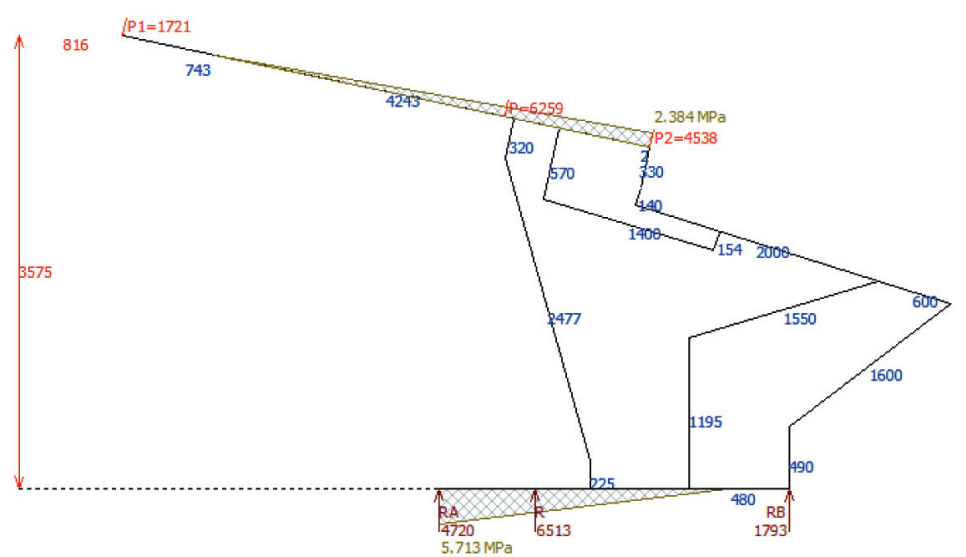

Rys. 3. Model 3, sekcja OBUD-2, wysokość wyrobiska około 3,5 m, stropnica podniesiona pod kątem $12^{\circ}$

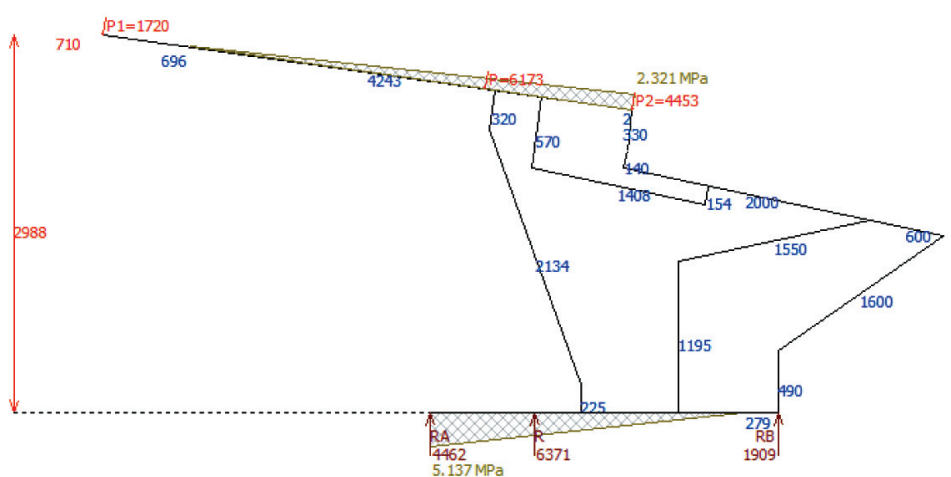

Rys. 4. Model 4, sekcja OBUD-2, wysokość wyrobiska około 3,0 m, stropnica podniesiona pod kątem $8^{\circ}$ 


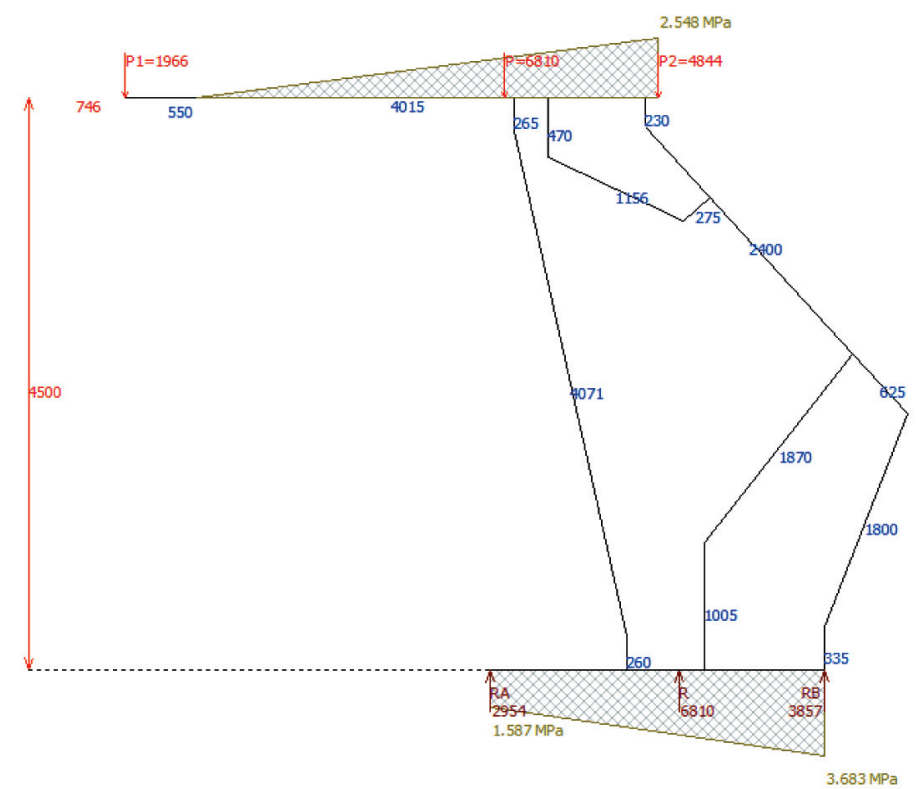

Rys. 5. Model 5, sekcja OBUD-1, wysokość wyrobiska 4,5 m, stropnica pozioma (kąt $0^{\circ}$ )

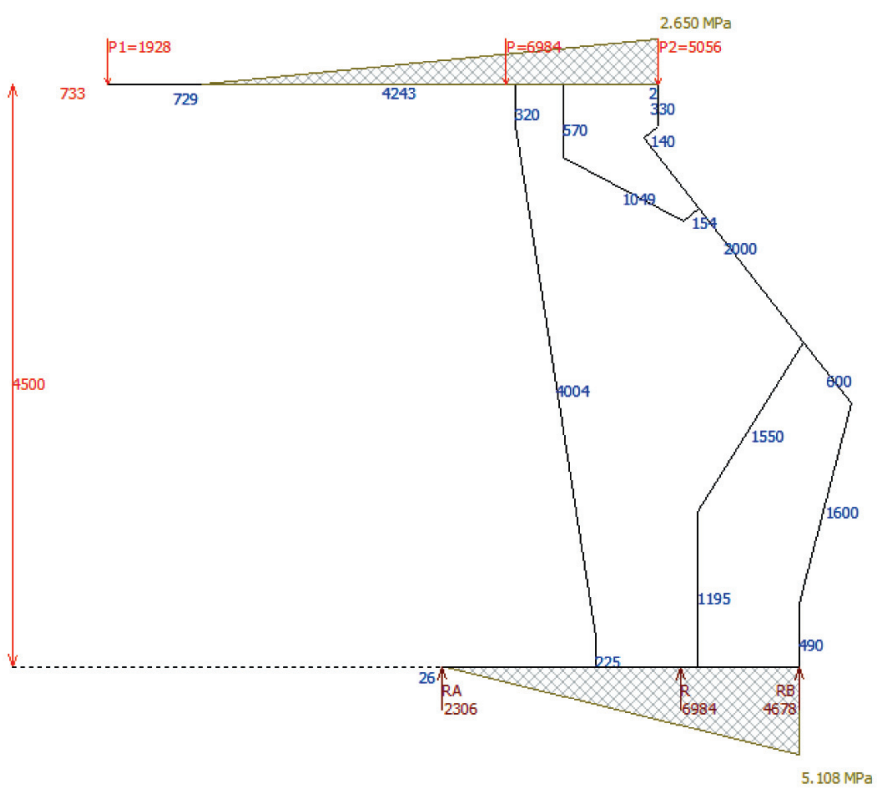

Rys. 6. Model 6, sekcja OBUD-2, wysokość wyrobiska 4,5 $\mathrm{m}$, stropnica pozioma (kat $0^{\circ}$ )

\section{OBLICZENIA ANALITYCZNE SIK W WEZZŁACH SEKCJI Z RÓŻNYM OBCIAZZŻEIEM OSŁONY ODZAWAŁOWEJ I NACHYLENIEM STROPNICY}

\subsection{Obciążenie sekcji przy niskich wysokościach roboczych}

Ze względu na obserwowane pod ziemią zaleganie gruzowiska zawałowego na osłonach odzawałowych sekcji, w przeprowadzonych obliczeniach postanowiono zasymulować możliwość ich różnego obciążenia. Rozważono następujące warianty przypadków obciążenia ze strony górotworu sekcji OBUD-1 i OBUD-2, często stosowane podczas analizy konstrukcji lub pracy obudów zmechanizowanych:

1) brak obciążenia osłony odzawałowej;

2) obciążenie o wartości $100 \mathrm{kN} / \mathrm{m}^{2}$ - taka wartość obciążenia osłony bywała zakładana w górnictwie niemieckim i wynikała $\mathrm{z}$ warunku stabilizacji przegubu stropnicy i osłony odzawałowej [6] (obciążenie takie odpowiada ciężarowi kamiennej kolumny o wysokości $4 \mathrm{~m}$ ), co potwierdziły doświadczenia ruchowe;

3) obciążenie punktowe osłony zawałowej siłą pionową $600 \mathrm{kN}$ umiejscowioną w środku długości osłony, jakie stosuje się w analizach wykonywanych przez konstruktorów sekcji. 
Wartości tych obciążeń postanowiono porównać $\mathrm{z}$ rezultatami innych obliczeń, $w$ tym przypadku z badaniami przeprowadzonymi według metody postępowania zaprezentowanego $\mathrm{w}$ [7].

Obliczenia wykonane $\mathrm{z}$ uwzględnieniem wymiarów sekcji OBUD-1 i OBUD-2 pokazały, że można spodziewać się obciążenia osłon odzawałowych o stosunkowo szerokiej zmienności wartości około 300-950 kN, w zależności od zakładanych parametrów, przy czym stosunek obciążenia osłony odzawałowej do obciążenia stropnicy, przy obniżaniu się wysokości sekcji (w zależności od rozpatrywanych warunków), może się zmieniać od około 41\% do 73\% dla sekcji OBUD-1 oraz od około $30 \%$ do $58 \%$ dla sekcji OBUD-2.

Rozważane wartości obciążeń są więc w dużej mierze porównywalne, niemniej jednak należy je oceniać $\mathrm{z}$ pewnym przybliżeniem, gdyż $\mathrm{w}$ interpretowanym schemacie obliczeń nie rozważano obciążeń dla stropnic nachylonych.

\subsection{Siły w węzłach konstrukcyjnych sekcji obudów zmechanizowanych}

Wraz ze zmianą podporności sekcji wahaniom ulegają wartości sił występujących w jej węzłach konstrukcyjnych, wpływające na wartości naprężeń i decydujące o trwałości całej konstrukcji lub jej elementów.
W celu przeprowadzenia analizy sił w węzłach konstrukcyjnych posłużono się modelem obliczeniowym, który umożliwia wyliczenie geometrii i sił w sekcji obudowy zmechanizowanej według schematów przedstawionych na rysunkach 7 i 8 .

Opracowany w Zakładzie Technologii i Obudów Górniczych GIG model obliczeniowy obudowy zmechanizowanej, zawarty w postaci programu komputerowego, pozwala na analizę jej podporności w funkcji wielu różnych parametrów występujących podczas pracy [5]. Można prowadzić obliczenia dotyczące praktycznie wszystkich typów sekcji zawałowych i podsadzkowych, stosowanych w polskich kopalniach węgla kamiennego. Uwzględniane są siły tarcia pomiędzy obudową a górotworem, powstające podczas poziomego ruchu stropnicy po krzywej lemniskatowej przy zmianie wysokości roboczej. Praktyka pokazuje, że siły te należy uwzględniać $\mathrm{w}$ obliczeniach statycznych obudowy, gdyż generują wewnętrzne naprężenia w elementach obudowy i wpływają na jej stateczność, zwłaszcza w fazie rozpierania.

Obliczenia można prowadzić dla stropnic równoległych i nachylonych względem spągu wyrobiska ścianowego, a kierunek działania sił zewnętrznych jest prostopadły względem stropnicy. Zależności wyliczane są jak dla belek sztywnych.

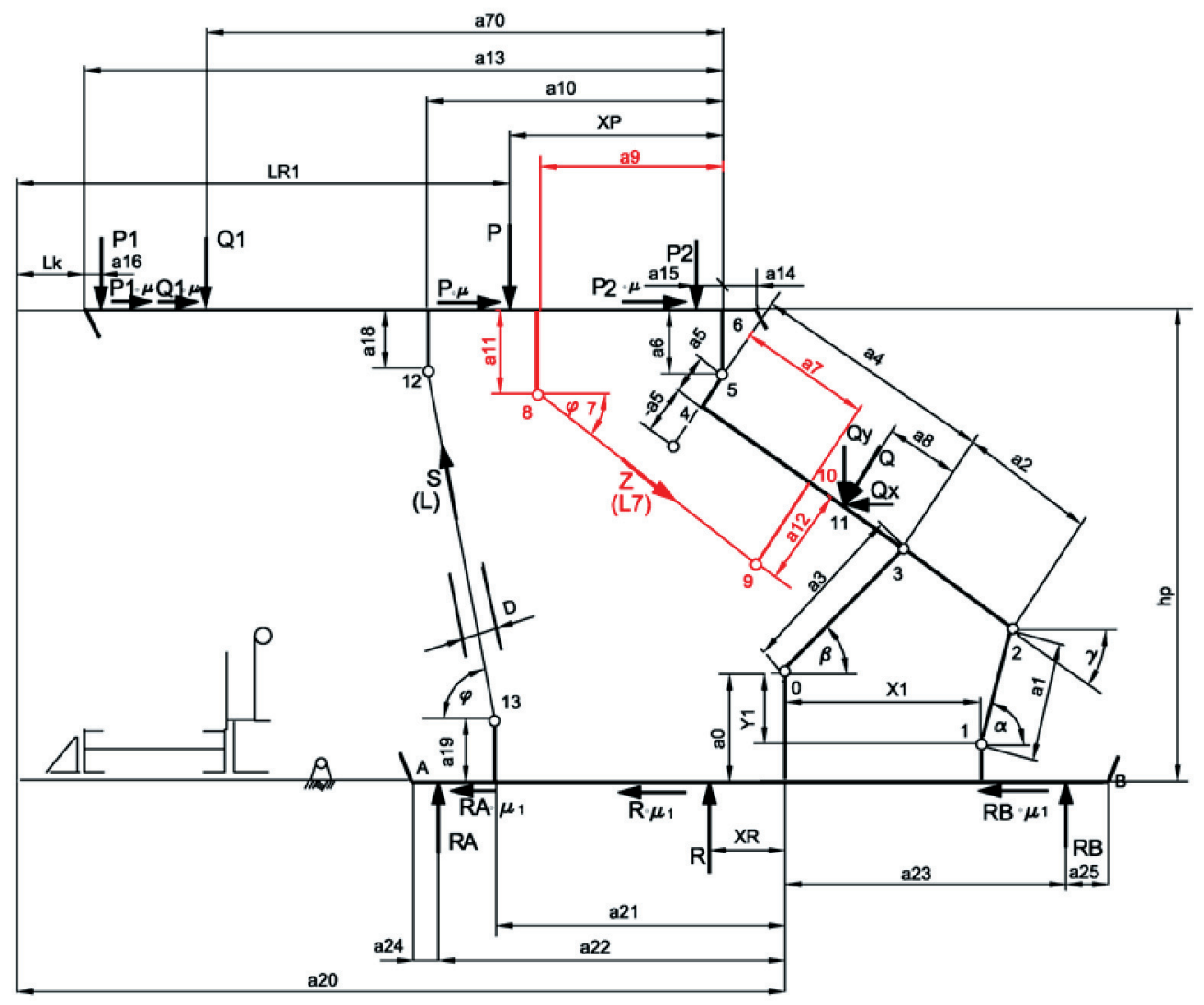

Rys. 7. Schemat geometrii sekcji obudowy zmechanizowanej 


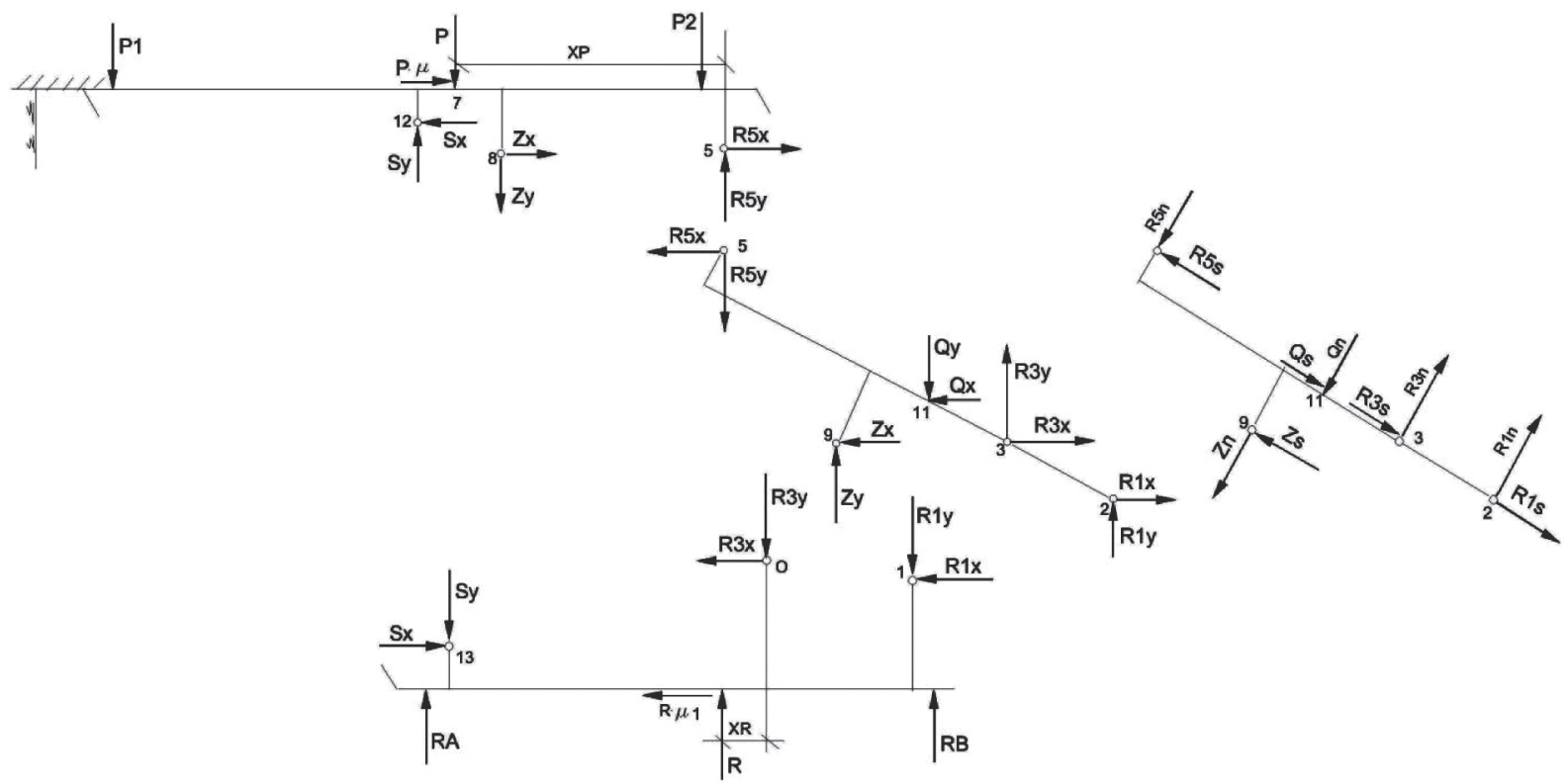

Rys. 8. Schemat rozkładu sił w węzłach sekcji obudowy zmechanizowanej

Obliczenia wartości sił można prowadzić dla układów sił:

- pochodzących od nacisku górotworu na stropnicę obudowy, symulując występowanie dodatkowych sił zewnętrznych oraz nacisku skał zawałowych na osłonę odzawałowa, przy zadanej podporności roboczej stojaków,

- występujących w czasie rozpierania obudowy, z podpornością wstępną wynikającą z ciśnienia zasilania stojaków, uwzględniając w tym przypadku zmianę zwrotu sił tarcia.

Opracowany model obliczeniowy umożliwia analizowanie sił tarcia: $\mathrm{z}$ badaniem i uwzględnieniem kierunku siły tarcia wynikającym z przebiegu krzywej lemniskatowej przy zmianie wysokości obudowy, a także przy założeniu niezmienności kierunku siły tarcia przy zmianie wysokości obudowy.

Ze względu na wnioski wynikające $\mathrm{z}$ obserwacji dołowych oraz uzyskanych postaci geometrii sekcji obudów dla modeli przedstawionych na rysunkach 1-4, szczególną uwagę zwrócono na obliczenia sił: R5x, R5y, R5n i R5s, jako składowych siły R5, związanej z przegubem stropnicy z osłoną odzawałową.

Dla każdej z sekcji wykonano obliczenia wartości tej siły w zależności od wysokości roboczej sekcji, dla kątów nachylenia stropnicy: $0^{\circ}, 8^{\circ}$ i $12^{\circ}$ oraz dla trzech wariantów obciążeń.

Wyniki obliczeń przedstawiono w tabelach 1 i 2 oraz na rysunkach 9 i 10 .

Tabela 1

Wartości siły R5 [kN] w węźle przegubu stropnicy z osłoną odzawałową dla sekcji liniowej OBUD-1

\begin{tabular}{|c|c|c|c|c|c|c|c|c|c|}
\hline \multirow{4}{*}{$\begin{array}{c}\text { Wysokość sekcji } \\
\text { (dla ukladu } \\
\text { lemniskatowego) } \\
\text { [m] }\end{array}$} & \multicolumn{9}{|c|}{ Nachylenie stropnicy } \\
\hline & \multicolumn{3}{|c|}{$\mathbf{0}^{\circ}$} & \multicolumn{3}{|c|}{$8^{\circ}$} & \multicolumn{3}{|c|}{$12^{\circ}$} \\
\hline & \multicolumn{3}{|c|}{ obciążenie osłony } & \multicolumn{3}{|c|}{ obciążenie osłony } & \multicolumn{3}{|c|}{ obciążenie osłony } \\
\hline & 0 kN & $100 \mathrm{kN} / \mathrm{m}^{2}$ & $600 \mathrm{kN}$ & $0 \mathrm{kN}$ & $100 \mathrm{kN} / \mathrm{m}^{2}$ & $600 \mathrm{kN}$ & $0 \mathrm{kN}$ & $100 \mathrm{kN} / \mathrm{m}^{2}$ & $600 \mathrm{kN}$ \\
\hline 2,4 & 1276 & 1394 & 1454 & 1975 & 2046 & 2084 & 2302 & 2353 & 2381 \\
\hline 2,7 & 816 & 944 & 1025 & 1587 & 1661 & 1708 & 1946 & 1998 & 2033 \\
\hline 2,9 & 563 & 699 & 799 & 1371 & 1444 & 1499 & 1747 & 1797 & 1838 \\
\hline 3,3 & 168 & 335 & 497 & 1027 & 1092 & 1167 & 1428 & 1471 & 1523 \\
\hline 3,7 & 115 & 203 & 403 & 775 & 829 & 930 & 1194 & 1226 & 1293 \\
\hline 4,1 & 332 & 321 & 449 & 584 & 625 & 761 & 1014 & 1038 & 1124 \\
\hline 4,5 & 554 & 525 & 548 & 408 & 440 & 633 & 851 & 872 & 997 \\
\hline
\end{tabular}


Tabela 2

Wartości siły R5 [kN] w węźle przegubu stropnicy z osłoną odzawałową dla sekcji liniowej OBUD-2

\begin{tabular}{|c|c|c|c|c|c|c|c|c|c|}
\hline \multirow{4}{*}{$\begin{array}{c}\text { Wysokość sekcji } \\
\text { (dla ukladu } \\
\text { lemniskatowego) } \\
{[\mathrm{m}]}\end{array}$} & \multicolumn{9}{|c|}{ Nachylenie stropnicy } \\
\hline & \multicolumn{3}{|c|}{$\mathbf{0}^{\circ}$} & \multicolumn{3}{|c|}{$\mathbf{8}^{\circ}$} & \multicolumn{3}{|c|}{$12^{\circ}$} \\
\hline & \multicolumn{3}{|c|}{ obciążenie osłony } & \multicolumn{3}{|c|}{ obciążenie osłony } & \multicolumn{3}{|c|}{ obciążenie osłony } \\
\hline & $0 \mathbf{k N}$ & $100 \mathrm{kN} / \mathrm{m}^{2}$ & $600 \mathrm{kN}$ & $0 \mathbf{k N}$ & $100 \mathrm{kN} / \mathrm{m}^{2}$ & $600 \mathrm{kN}$ & $0 \mathrm{kN}$ & $100 \mathrm{kN} / \mathrm{m}^{2}$ & $600 \mathrm{kN}$ \\
\hline 2,4 & 635 & 765 & 857 & 1370 & 1443 & 1503 & 1707 & 1761 & 1807 \\
\hline 2,7 & 175 & 345 & 499 & 987 & 1067 & 1147 & 1358 & 1417 & 1476 \\
\hline 2,9 & 72 & 216 & 394 & 776 & 858 & 955 & 1164 & 1222 & 1292 \\
\hline 3,3 & 439 & 416 & 499 & 454 & 532 & 675 & 865 & 913 & 1007 \\
\hline 3,7 & 668 & 639 & 680 & 244 & 309 & 520 & 669 & 700 & 821 \\
\hline 4,1 & 816 & 795 & 810 & 109 & 151 & 446 & 544 & 558 & 707 \\
\hline 4,5 & 1030 & 1024 & 932 & 30 & 30 & 396 & 424 & 427 & 643 \\
\hline
\end{tabular}

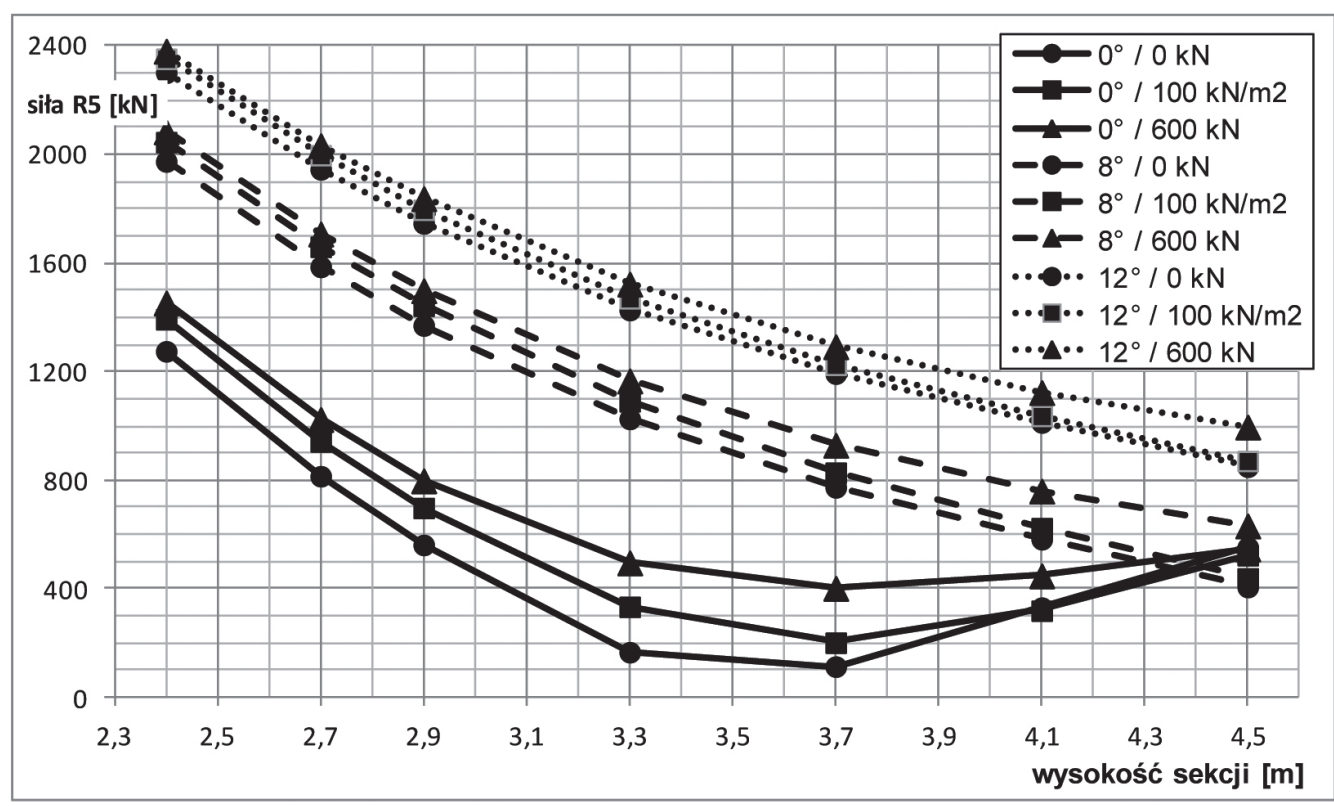

Rys. 9. Wartości sity R5 w węźle przegubu stropnicy z osłona odzawałowa dla sekcji liniowej OBUD-1

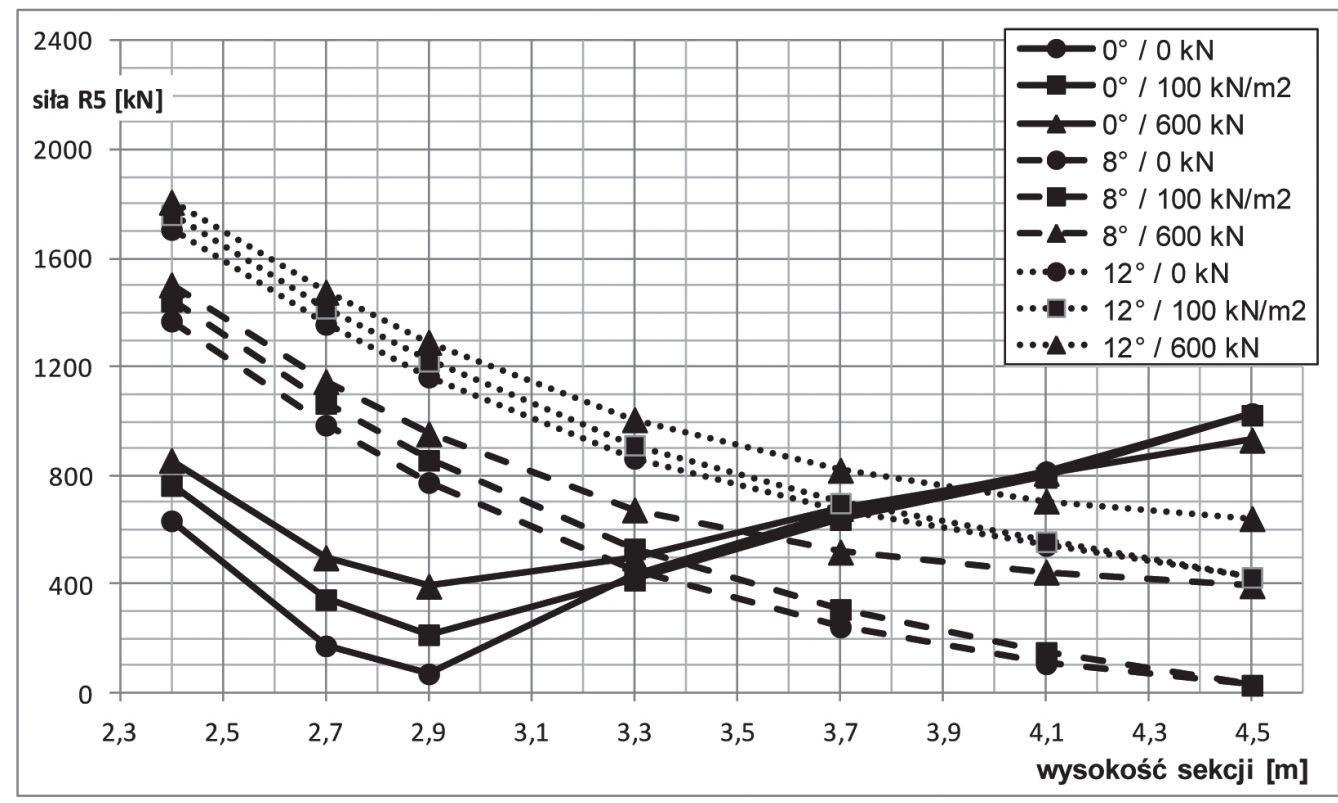

Rys. 10. Wartości sity R5 w węźle przegubu stropnicy z osłona odzawałowa dla sekcji liniowej OBUD-2 


\section{PODSUMOWANIE}

Na podstawie analizy zdefiniowanych modeli obliczeniowych sekcji obudów OBUD-1 i OBUD-2 oraz wariantowych wyliczeń obciążenia można stwierdzić, że wartości sił w węzłach konstrukcyjnych tych sekcji mogą znacznie się różnić od modelu przyjmowanego zwykle w DTR dla maksymalnej wysokości roboczej i poziomego usytuowania stropnicy i spągnicy.

Zmiany wartości siły w węźle przegubu stropnicy z osłoną odzawałową (R5 na rysunku 8), na podstawie przedstawionych obliczeń i wykresów, zależą przede wszystkim od konkretnej postaci kinematyki (wymiarów geometrycznych) sekcji, w tym przypadku OBUD-1 lub OBUD-2, następnie od nachylenia pomiędzy stropnicą a spągnicą i od obciążenia osłony odzawałowej sekcji.

Dla wysokości układu lemniskatowego sekcji OBUD-1 i OBUD-2 (2,4 m i 2,7 m) oraz kątów nachyleń ich stropnic $\left(8^{\circ}\right.$ i $\left.12^{\circ}\right)$, wartości tej siły są wyraźnie większe od wartości wyliczonych dla wysokości $4,5 \mathrm{~m}$ i pracy ze stropnicą poziomą. W przypadku sekcji OBUD-1 mogą być one większe nawet o około 4,3 razy, natomiast w przypadku sekcji OBUD-2 o około 1,8 razy. Dodatkowe obliczenia wykazały ponadto, że przy rozpieraniu sekcji siły te mogą jeszcze znacznie wzrastać.

Przy ułożeniu stropnicy i osłony w niemal jednej linii nachylenie siły R5 skierowane było często niemal zgodnie z kierunkiem składowej siły R5s (rys. 8) oraz linią podpory stropnicy. Biorąc pod uwagę fakt, że podpora charakteryzowała się maksymalną siłą $588 \mathrm{kN}$ pod tłokiem lub $703 \mathrm{kN}$ nad tłokiem, jej zmiany mogły mieć znikomy wpływ na możliwość korekcji położenia stropnicy. W takich warunkach operowanie podporą stropnicy było nieefektywne lub nawet wręcz niemożliwe, a sekcje wykazywały tendencję do tworzenia jednej płaszczyzny przez stropnicę i osłonę odzawałową, aż do położenia wynikającego z ograniczników podpory i/lub maksymalnego wysunięcia siłowników.

W warunkach ściany 124 powodowało to pracę sekcji z uniesioną stropnicą i efekt liniowego podpierania stropu, przez co dochodziło do niszczenia jego struktury oraz opadu. W tym konkretnym przypadku przerywanie ciągłości ochronnej półki węglowej pozostawianej w pułapie wyrobiska skutkowało opadem gruzowiska zawałowego i istotnymi utrudnieniami podczas eksploatacji.

Można wyrazić przypuszczenie, że w przypadku prowadzenia tych sekcji w podobnej konfiguracji, lecz pod stropem naturalnym, gdzie półka węglowa nie jest wymagana do izolacji słabej warstwy w stropie bezpośrednim (np. zrobów zawałowych), może nie dochodzić do opadów o takiej intensywności, jeśli wy- trzymałość mechaniczna stropu będzie wystarczająca, niemniej nadal panować będą warunki do jego „podcinania” na skutek trudności z korekcją położenia stropnic.

Zaprezentowane na rysunkach 9 i 10 wykresy wskazują, że dla sekcji OBUD-1 przyrost siły R5 w węźle łączącym stropnicę z osłoną jest większy od skali przyrostu obserwowanego dla sekcji OBUD-2, niekorzystne zjawiska mogą więc wystąpić dla innych, wyższych wysokości roboczych obudowy niż dla OBUD-2. Praktyka pokazała, że trudności w ścianie 124 ustępowały przy utrzymywaniu wysokości roboczych większych od około 3,5 $\mathrm{m}$.

Praca sekcji z niewłaściwą geometrią (rys. 1-4) powoduje ponadto generowanie zwiększonych nacisków w przedniej części spągnicy, co w przypadku pracy na słabych spagach może powodować dodatkowe utrudnienia w prowadzeniu ściany.

Niekorzystnym zjawiskiem była także możliwość nadmiernego gromadzenia się gruzowiska zawałowego na osłonach wynikająca $z$ niewielkich kątów ich nachylenia oraz dużych powierzchni osłon (z racji ich stosunkowo dużych długości).

$\mathrm{Z}$ wyliczeń przeprowadzonych na modelach wynika, że dla sekcji OBUD-1 dla modeli 1 i 2 (rys. 1,2) kąty te przy wysokości ściany około $3,5 \mathrm{~m}$ i około $3,0 \mathrm{~m}$ wynosiły odpowiednio $19,8^{\circ}$ i $15,3^{\circ}$. Dla porównania przy prawidłowej geometrii sekcji i wysokościach pracy $3,0 \mathrm{~m}, 3,5 \mathrm{~m}$ i 4,5 m kąty te uzyskują odpowiednio wartości: $24,1^{\circ}, 31,2^{\circ}$ i $48,1^{\circ}$ (rys. 11). Dla sekcji OBUD-2, w modelach 3 i 4 (rys. 3, 4) kąty nachylenia osłony odzawałowej w kierunku spagu wyrobiska wynosiły odpowiednio $17,4^{\circ}$ i $11,9^{\circ}$. Podobnie jak wcześniej - dla porównania przy prawidłowej geometrii sekcji i wysokościach pracy 3,0 m, 3,5 m i 4,5 m kąty te uzyskują odpowiednio wartości: $22,4^{\circ}, 27,5^{\circ}$ i $51,9^{\circ}$ (rys. 11 ).

Małe wartości kątów nachylenia osłon odzawałowych przy niskich wysokościach pracy sekcji mogą w istotny sposób wpływać na obciążenie sekcji oraz ich prawidłową współpracę z górotworem w celu zapewnienia stateczności wyrobiska ścianowego. Kąty nachylenia osłon odzawałowych mniejsze niż $30^{\circ}$ są często zbyt małe, aby pokonać siłę tarcia pojawiającą się przy kontakcie osłony odzawałowej z luźnymi skałami pochodzacymi z zawału [8], w przypadku możliwości ich zsuwania się. Przyczynia się to do nadmiernego gromadzenia się materiału zawałowego na sekcji, co w połączeniu z bardzo dużą powierzchnią osłon odzawałowych wynikającą z ich długości - determinowanej głównie szerokim zakresem wysokości pracy sekcji 2,4-4,6 $\mathrm{m}$ - powoduje zarówno dodatkowe istotne obciążenie analizowanych sekcji, jak i wzrost sił w węzłach konstrukcyjnych. 


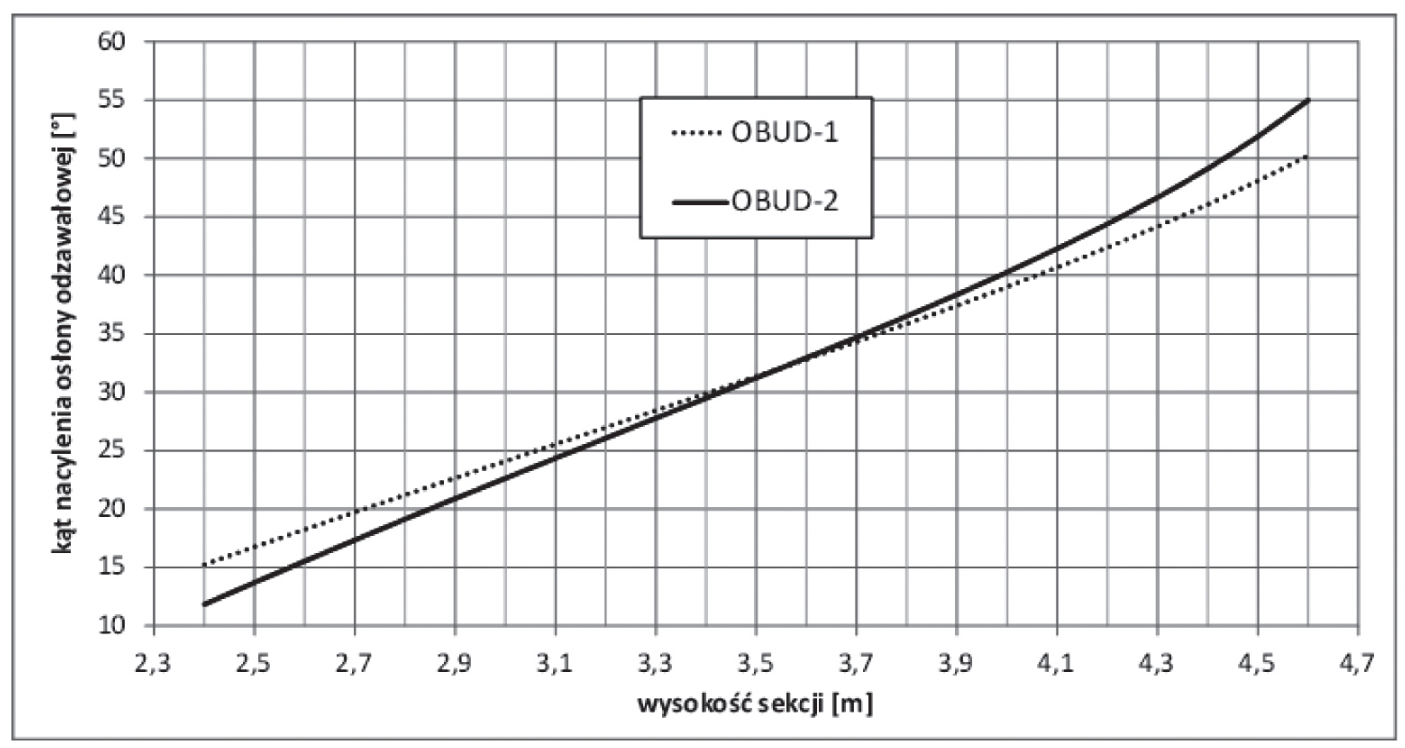

Rys. 11. Katy nachylenia ostony odzawatowej w sekcjach OBUD-1 i OBUD-2 przy prawidłowej geometrii

W analizowanych przypadkach obciążenie osłon odzawałowych gruzowiskiem zawałowym, w przypadku niskich wysokości pracy sekcji i nieprawidłowej geometrii (modele $1-4$, rys. 1-4), powodować mogło obniżenie podporności obudów wynoszące do $17,5 \%$ w stosunku do warunków określanych w DTR dla wysokości 4,5 $\mathrm{m}$ z poziomą stropnicą.

\section{WNIOSKI}

Na podstawie przeprowadzonych obserwacji, obliczeń i analiz można sformułować następujące wnioski:

1. Główną przyczyną utrudnień w zapewnieniu stateczności wyrobiska ściany 124 (powstawania obwałów) w przypadku prowadzenia sekcji OBUD-1 i OBUD-2 w dolnym zakresie wysokości roboczych, była niewłaściwa geometria sekcji, polegająca na utworzeniu się niemal jednej płaszczyzny pomiędzy osłoną odzawałową i stropnicą. W konkretnym przypadku ściany 124 powodowało to liniowe podparcie pułapu wyrobiska i jego uszkodzenie, w konsekwencji prowadząc do przerwania półki węglowej i opadu gruzowiska zawałowego $\mathrm{z}$ warstwy przystropowej.

2. Niewłaściwa geometria sekcji związana była $z$ istotnym wzrostem sił w węźle przegubu stropnicy z osłoną odzawałową, które mogły praktycznie uniemożliwić skuteczną korekcję położenia stropnicy za pomocą podpory stropnicy.
3. Wartości sił w węźle przegubu stropnicy z osłoną odzawałową, w przypadku sekcji OBUD-1 i OBUD-2 zależą w analizowanych przypadkach niskich wysokości roboczych przede wszystkim od wymiarów geometrycznych sekcji, następnie od kąta nachylenia pomiędzy stropnicą a spągnicą oraz od obciążenia osłony odzawałowej sekcji.

4. Przeprowadzone obliczenia wskazują, że omawiane utrudnienia w analizowanych sekcjach są związane przede wszystkim $\mathrm{z}$ niskimi wysokościami pracy. Praktyka pokazała, że trudności w ścianie 124 ustępowały przy utrzymywaniu wysokości roboczych większych od około $3,5 \mathrm{~m}$.

5. Praca sekcji z niewłaściwą geometrią, o której mowa w artykule, powoduje generowanie bardzo dużych wartości nacisków w przedniej części spągnicy, co także w przypadku pracy na słabych spągach może powodować dodatkowe utrudnienia w prowadzeniu ściany.

\section{Podziękowania}

W artykule wykorzystano wyniki prac wykonanych w ramach realizacji projektu PRASS III: „Produktywność i bezpieczeństwo obudów zmechanizowanych” (Productivity and Safety of Shield Support), współfinansowanego przez Fundusz Badawczy dla Węgla i Stali (Research Fund for Coal and Steel) (kontrakt nr 752504) oraz Ministerstwo Nauki i Szkolnictwa Wyższego. 


\section{Literatura}

[1] Masny W., Prusek S., Walentek A.: Pomiary konwergencji oraz obciażenia działajacego na obudowę wyrobisk korytarzowych zlokalizowanych pod zrobami zawatowymi wraz z metoda oceny ich rekonsolidacji, Międzynarodowa Konferencja Naukowo-Techniczna „Górnicze Zagrożenia Naturalne”. „Prace Naukowe GIG. Górnictwo i Środowisko” 2011, 4/2: 297-304.

[2] Płonka M. et al.: Wykonanie pracy naukowo-badawczej określającej możliwości stosowania, upodatnienia $i$ warunki wspótpracy sekcji obudów zmechanizowanych różnych typów dla ściany 124 w poktadzie 510, poz. $500 \mathrm{~m} w \mathrm{KHW}$ SA KWK Mystowice-Wesoła, Praca badawczo-usługowa GIG o symbolu 581 07936-152, GIG, Katowice 2016 [praca niepublikowana].

[3] Rajwa S., Prusek S., Szuścik J., Gąska R.: Prowadzenie ściany pod gruzowiskiem zawałowym w warunkach zmiennej grubości pozostawionej warstwy przyspagowej, „Przegląd Górniczy” 2017, 6: 33-37.

[4] Płonka M. et al.: Opracowanie dotyczace wykonania oceny wspótpracy z górotworem sekcji obudowy zmechanizowanej $w$ zakresie roboczym tej obudowy, Praca badawczo-usługowa GIG o symbolu 581 35956-152, GIG, Katowice 2016 [praca niepublikowana].
[5] Płonka M., Rajwa S.: Podporność i rozkład sit w węzłach sekcji obudowy zmechanizowanej, „Wiadomości Górnicze” 2009, 10: 611-616.

[6] Irresberger H., Gräwe F., Migenda P.: Zmechanizowane obudowy ścianowe, Wydawnictwo Tiefenbach Polska Sp. z o.o., Piekary Śląskie 2003.

[7] Losiak S., Ptak J.: Wplyw gruzowiska zawatowego na ostone odzawałowa i zachowanie się sekcji lemniskatowej obudowy ścianowej, „Mechanizacja i Automatyzacja Górnictwa” 2010, 3: 35-41.

[8] Frith Russell C.: A holistic examination of the load rating design of longwall shields after more than half a century of mechanised longwall mining, „International Journal of Mining Sciences and Technology" 2015, 25: 687-706.

dr inż. MAREK PŁONKA dr inż. SYLWESTER RAJWA

Zakład Technologii Eksploatacji i Obudów Górniczych Gtówny Instytut Górnictwa pl. Gwarków 1, 40-166 Katowice \{mplonka,srajwa\}@gig.eu 